\title{
34. SITE 570 METHANE HYDRATE ZONE 1
}

\author{
Mark A. Mathews, Los Alamos National Laboratory \\ and \\ Roland von Huene, U.S. Geological Survey, Menlo Park, California ${ }^{2}$
}

\begin{abstract}
Deep Sea Drilling Project (DSDP) studies at Site 570 on the landward slope of the Middle America Trench off Guatemala allow for the first time a quantitative estimate of the methane hydrate content in the massive mudstones deposited there. Drilling across the Guatemalan transect on DSDP Legs 67 and 84 has resulted in the greatest number of visual observations of gas hydrate in any marine area. At Site 570, a 1.5-m-long section of massive methane hydrate was unexpectedly cored in an area where none of the usual signs of gas hydrate in seismic records were present. The sediment section is similar to that recovered at the other eight sites off Guatemala, but drilling at Site 570 may have penetrated through a fault zone that provided the space for accumulation of massive gas hydrate.

The methane hydrate was analyzed using the following well logs: density, sonic, resistivity, gamma-ray, caliper, neutron porosity, and temperature. The density, sonic, and resistivity logs define a 15 -m-thick hydrated zone within which a 4-m-thick nearly pure hydrate section is contained. The methane gas content ranges from $240 \mathrm{~m}^{3}$ to $1400 \mathrm{~m}^{3}$ per $\mathrm{m}^{2}$ of lateral extent; and if the body extends a square kilometer, its total volume of stored gas could be from $240 \times 10^{6} \mathrm{~m}^{3}$ to $1400 \times 10^{6} \mathrm{~m}^{3}$

Because the acoustic impedance of hydrate calculated from the sonic and density logs shows no anomalous values, the shape and extent of the hydrate body cannot be defined in seismic records. Thus the body is theoretically nonreflective in contrast to the base of the hydrate reflection. The base of the gas hydrate reflection is presumed to be the result of the velocity contrast between sediment containing gas hydrate and sediment containing free gas.
\end{abstract}

\section{INTRODUCTION}

During Leg 84 , gas hydrate was recovered or indicated from pore-water chemistry at all but one site (Site 567). The most informative occurrence was at Site 570 where massive rather than dispersed hydrate was encountered. The hole, continuously cored through sediment of the slope and well into the underlying igneous basement, probably contained hydrate over its full length. Because of the unusually thick zone of massive gas hydrate, a full suite of downhole logs was obtained to complement the geochemical study of the hydrate.

The geologic setting of Site 570 has some unusual aspects, namely, a large transverse furrow $18 \mathrm{~km}$ long, which we interpret as a fault, and the proximity of a highly magnetic basement. The site is on the upper slope of the Middle America Trench off Guatemala, about $15 \mathrm{~m}$ from the edge of the shelf on a break in slope about $1700 \mathrm{~m}$ deep. After Leg 84, a detailed geophysical survey was made that included the Seabeam instrument, which bathymetrically maps a continuous swath of ocean floor (Volpe et al., this volume). The bathymetric map and high-resolution seismic data indicate a major fault, transverse to the trend of the Trench, adjacent to the site. Multichannel as well as high-resolution seismic records show no bottom simulating reflection (BSR) to mark the base of the hydrate nor any other unusual indications to mark a hydrate accumulation (Ladd et al., 1982; von Huene et al., 1982; Volpe et al., this volume). The

\footnotetext{
${ }^{1}$ von Huene, R., Aubouin, J., et al., Init. Repts. DSDP, 84: Washington (U.S. Govt. Printing Office)

2 Addresses: (Mathews) Los Alamos National Laboratory, Los Alamos, NM 87545; (von Huene) U.S. Geological Survey, Menlo Park, CA 94025.
}

calculated base of hydrate depth falls below the sediment sequence and into the basement, which was one reason to select the site. The principal target was the highly magnetic basement rock that was thought to be a slice of imbricated ocean crust and, for safety reasons, a target above the depth of the base of the hydrate zone was preferred. The encountering of massive hydrate was unexpected.

Coring with $41 \%$ recovery yielded an upper unit of Holocene to Pliocene massive olive gray to greenish gray mud and mudstone: $13 \%$ of this sediment is composed of siliceous biogenic remains (see Site 570 site report) (Fig. 1). The first visual observations of gas hydrate were made near and at the bottom of this unit (at sub-bottom depths of about 192 and $240 \mathrm{~m}$, respectively). Below this, the core containing about $1.5 \mathrm{~m}$ of massive hydrate, capped by about $20 \mathrm{~cm}$ of sandstone and fractured dolomite with veins filled by calcite (249-259 m), was recovered. Immediately below and separated by a hiatus is an upper Miocene mudstone unit that is more lithified and fractured (259-326 m). The Miocene sequence is separated by another hiatus from a lower Miocene unit, which in turn unconformably overlies $36 \mathrm{~m}$ of lower Eocene sediment that rest on a serpentinite basement (Fig. 1). The lithology of the bottom $46 \mathrm{~m}$ of the sediment sequence is more varied than the sequences above, including carbonate and sandstone.

The distribution of gas was relatively typical in the upper part of the hole compared with other holes drilled on the Guatemalan margin. Methane dominated with increasing amounts of ethane down to the massive hydrate (Kvenvolden, this volume). From 100 to $210 \mathrm{~m}$ sub-bottom depth, $\mathrm{C}_{2}$ through $\mathrm{C}_{5}$ amounts increased (in the ppm range) and just above the massive hydrate were 

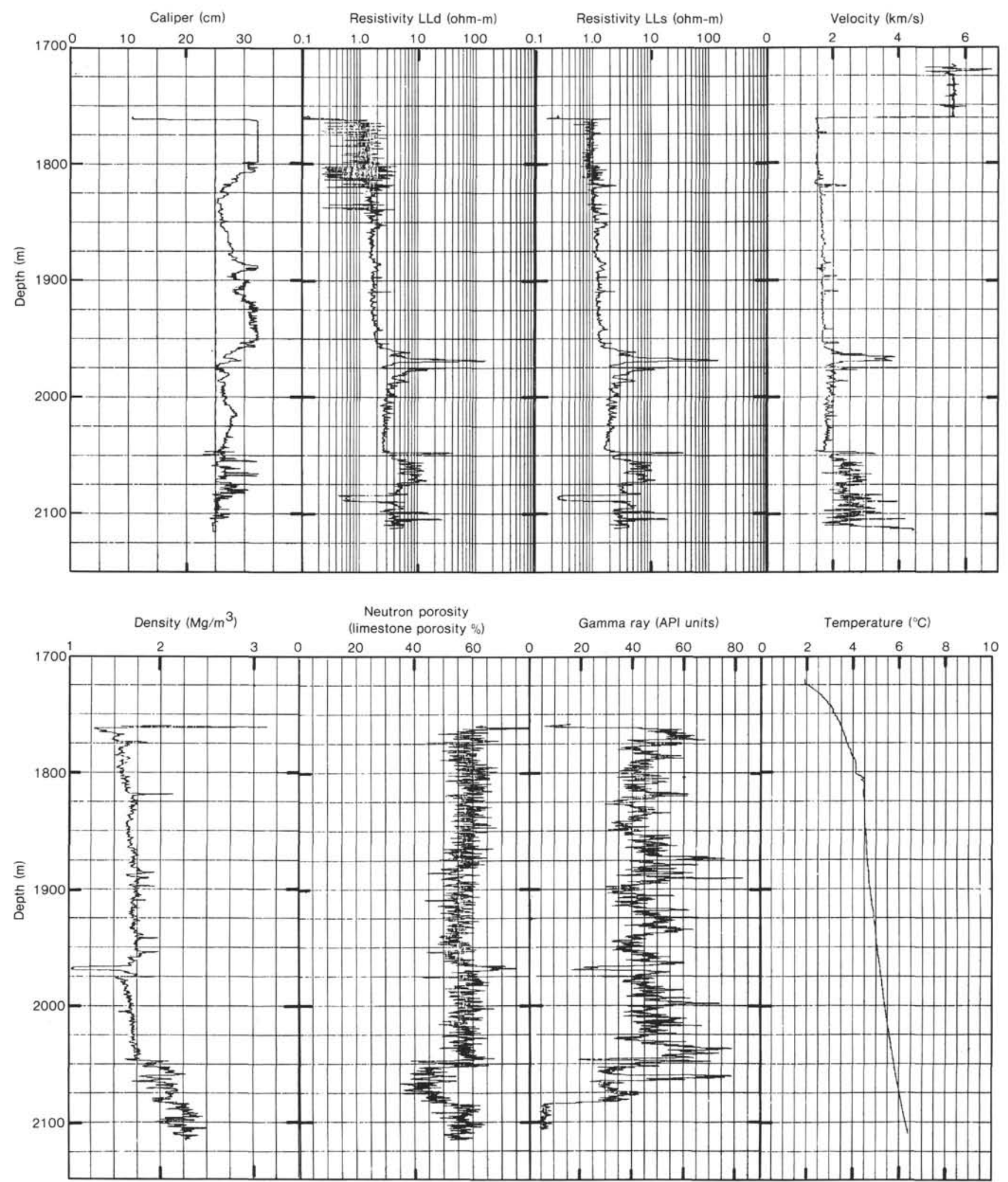

Figure 1. Site 570 logs (original vertical scale $2.5 \mathrm{~cm}=100 \mathrm{~m}$ ). The resistivity data are divided into two laterologs-LLd (deep laterolog) and LLs (shallow laterolog.) Depth is from the rig floor. 
observed to increase sharply; they remained constant downhole to about $350 \mathrm{~m}$; the basement was encountered at about $375 \mathrm{~m}$. Hydrocarbon species were continually detected in the serpentinite basement to total depth$401.5 \mathrm{~m}$.

The following table lists the logs obtained for Hole 570:

\begin{tabular}{cc}
\hline Logs run & Logs acquired \\
\hline I & $\begin{array}{c}\text { Caliper }(\mathrm{cm}), \text { gamma-ray (API units), compensated } \\
\text { density }\left(\mathrm{Mg} / \mathrm{m}^{3}\right) \text {, compensated thermal neutron } \\
\text { (limestone porosity units) }\end{array}$ \\
& $\begin{array}{c}\text { Self-potential }(\mathrm{m} v), \text { gamma-ray (API units), latero- } \\
\text { log deep (ohm-m), laterolog shallow }(\mathrm{ohm}-\mathrm{m})\end{array}$ \\
III & $\begin{array}{c}\text { Gamma-ray (API units), p-wave or } \Delta \mathrm{t} \text { sonic }(\mu \mathrm{s} / \mathrm{m} \\
\text { or km/s), and full-wave sonic }(\mu \mathrm{s})\end{array}$ \\
IV & Temperature $\left({ }^{\circ} \mathrm{C}\right)$ \\
\hline
\end{tabular}

The total depth (TD) information for Hole 570 is as follows: depth from the rig floor (RF) to $\mathrm{TD}=2120 \mathrm{~m}$; depth from sea level to TD $=2099.5 \mathrm{~m}$; and depth from ocean floor to TD $=401.5 \mathrm{~m}$.

All logs are referenced from the rig floor, and depths of logs used in plots or text throughout this chapter are based on the RF reference unless otherwise stated. To determine standard DSDP sub-bottom core depths, subtract $1718.5 \mathrm{~m}$.

The zone of methane hydrate is defined by the sonic $\log$ as 240 to $255 \mathrm{~m}$ below the ocean floor, or as 1958.5 to $1973.5 \mathrm{~m}$ below the RF reference. Also, the density, laterologs, neutron, and gamma-ray logs identify this zone as shown in Figure 1. A scale enlargement of these logs is shown in Figure 2. The hydrate zone is clearly defined by the low apparent density (approximately 1.05 $\mathrm{Mg} / \mathrm{m}^{3}$ ), the high apparent resistivities (approximately $155 \mathrm{ohm}-\mathrm{m}$ ), the high velocity (approximately $3.6 \mathrm{~km} / \mathrm{s}$ ), the high neutron porosity (approximately $67 \%$ ), and the low gamma-ray response (15-25 API units).

\section{LOG QUALITY AND GENERAL CORRECTIONS}

The quality of all the logs recorded for Hole 570 is very good to excellent. The general corrections of borehole size variation, drilling fluid invasion and mud cake, and depth variations between log runs are discussed in this section.

The caliper log (see Figs. 1 and 2) for the entire borehole (1860-2100 m) shows some enlargement. The bit size is $25 \mathrm{~cm}$, and the borehole varies in size from 25 to $33 \mathrm{~cm}$. This variation is reasonable for a borehole that was core drilled using seawater as the drilling fluid.

The caliper log through the methane hydrate interval of 1958.5 to $1973.5 \mathrm{~m}$ exhibits a borehole that is slightly enlarged from the bit size of $25 \mathrm{~cm}$, as shown in Figure 3 . This enlargement varies from 0 to $4 \mathrm{~cm}$, or the borehole varies in diameter from 25 to $29 \mathrm{~cm}$. Because the borehole diameter variation is small and the diameter is approximately $25 \mathrm{~cm}$ in this interval, the borehole correction, which would be minor for most of the logs in this interval, was neglected. Only the laterologs were corrected for the borehole size in this interval.
Hole 570 was core drilled using seawater as the drilling fluid. The connate water of the formations penetrated is similar to and has nearly the same characteristics as those of seawater (Kvenvolden, this volume). Consequently, invasion of drilling fluid and mud cake have little or no effect on all of the logs, and the corrections for these effects can be ignored.

Three gamma-ray logs were obtained. A separate gamma-ray log was obtained for each log run (except the temperature log run). The values of the API units of each gamma-ray log are somewhat different at similar depths, but the overall character of these logs (peaks and troughs) should correlate without depth shifting when plotted versus depth. If they are similar, then there are no depth variations between log runs and various logs can be compared using the recorded depth. If these gamma-ray logs are not similar, then depth corrections must be made before various logs can be compared by depth. A plot of the three gamma-ray logs is shown in Figure $4 \mathrm{~A}$ and $\mathrm{B}$. The gamma ray logs in Figure 4A have been smoothed with an 11-point running average filter (filter length is $1.524 \mathrm{~m}$ ). These logs show similar overall character with no large depth shifts among the different log runs for the entire borehole $(1760-2100 \mathrm{~m})$. The overall character through the interval of 1958.5 to $1973.5 \mathrm{~m}$, as seen in Figure 4B, is very similar for these three logs. Minor differences are probably the result of statistical variations (present in all nuclear measurements) and/or ship heave (present and not compensated or measured during logging). Because of the character similarity among the three gamma-ray logs through the entire borehole, no depth corrections were applied to the logs and all logs are compared by the depth measured from the RF.

\section{LOG DATA DESCRIPTION AND HYDRATE VALUES}

In this section, the following logs and their responses to general geology are discussed: temperature; full-wave sonic; p-wave or $\Delta t$ sonic; compensated density; dual laterolog; compensated thermal neutron porosity; and gamma ray. The self-potential (SP) log was recorded for Hole 570 , but its response is featureless, confirming that the resistivities of the borehole fluid, the mud filtrate, and the formation water are about equal.

The temperature log shown in Figure 5 was obtained while going down the hole (generally logs are obtained coming up the hole because of better depth control). This log was smoothed with an 11-point running average filter and shows a temperature increasing with depth. The temperature data also show two gradients: the first $75 \mathrm{~m}$ of the hole have an approximate temperature gradient of $33.3^{\circ} \mathrm{C} / \mathrm{km}$ (consistent with other temperature information, von Huene et al., 1982), and the next $300 \mathrm{~m}$ of the hole has an approximate temperature gradient of $6.7^{\circ} \mathrm{C} / \mathrm{km}$. No temperature variations are seen through the hydrate interval from 1958.5 to $1973.5 \mathrm{~m}$. The borehole temperature data are not in equilibrium with the surrounding formation temperature. A more detailed plot of the temperature through the hydrate interval is shown in Figure 6. A nearly constant gradient of $6.67^{\circ} \mathrm{C} / \mathrm{km}$ 


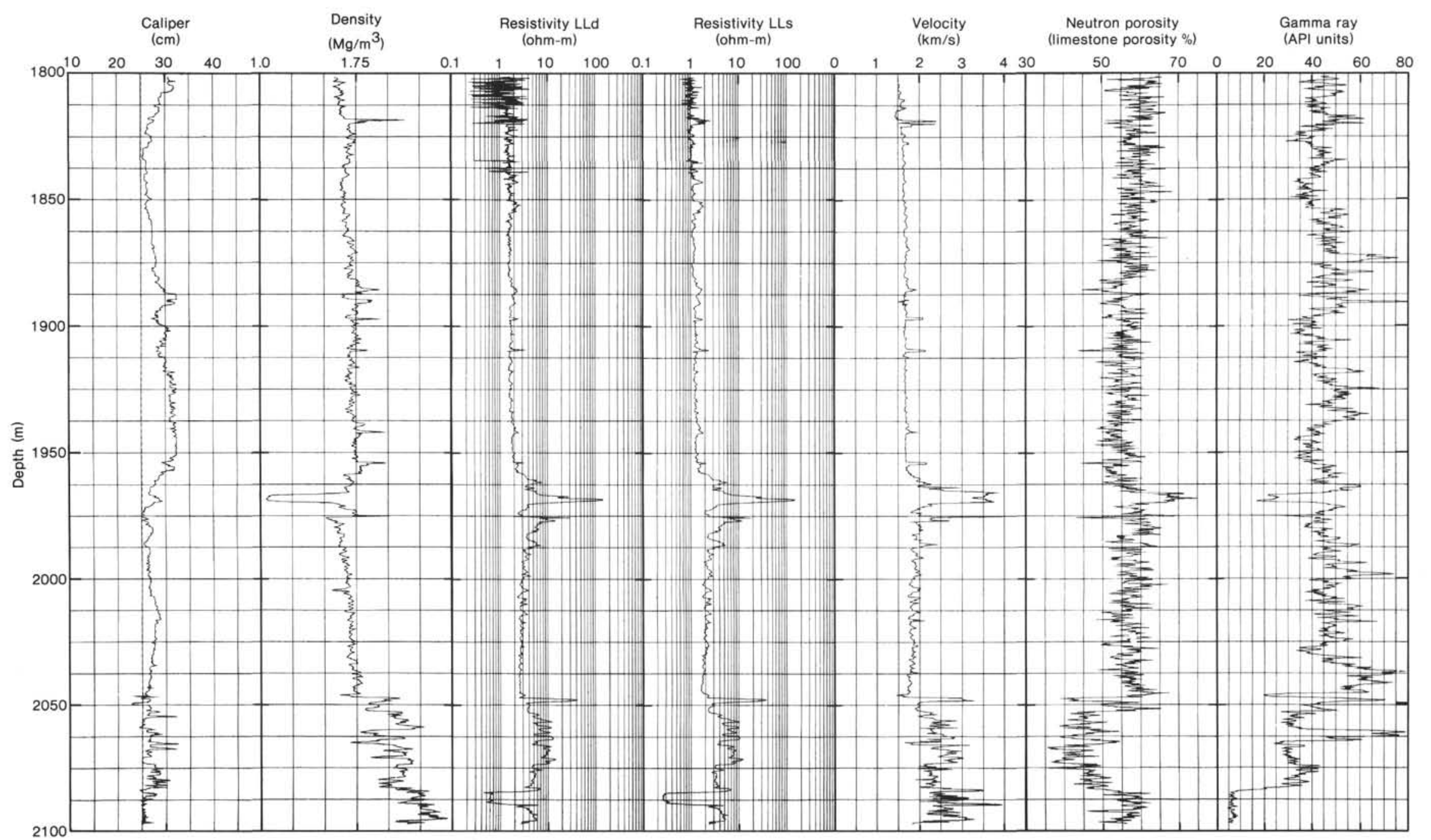

Figure 2. Site 570 logs (original vertical scale $10.0 \mathrm{~cm}=100 \mathrm{~m}$ ). 


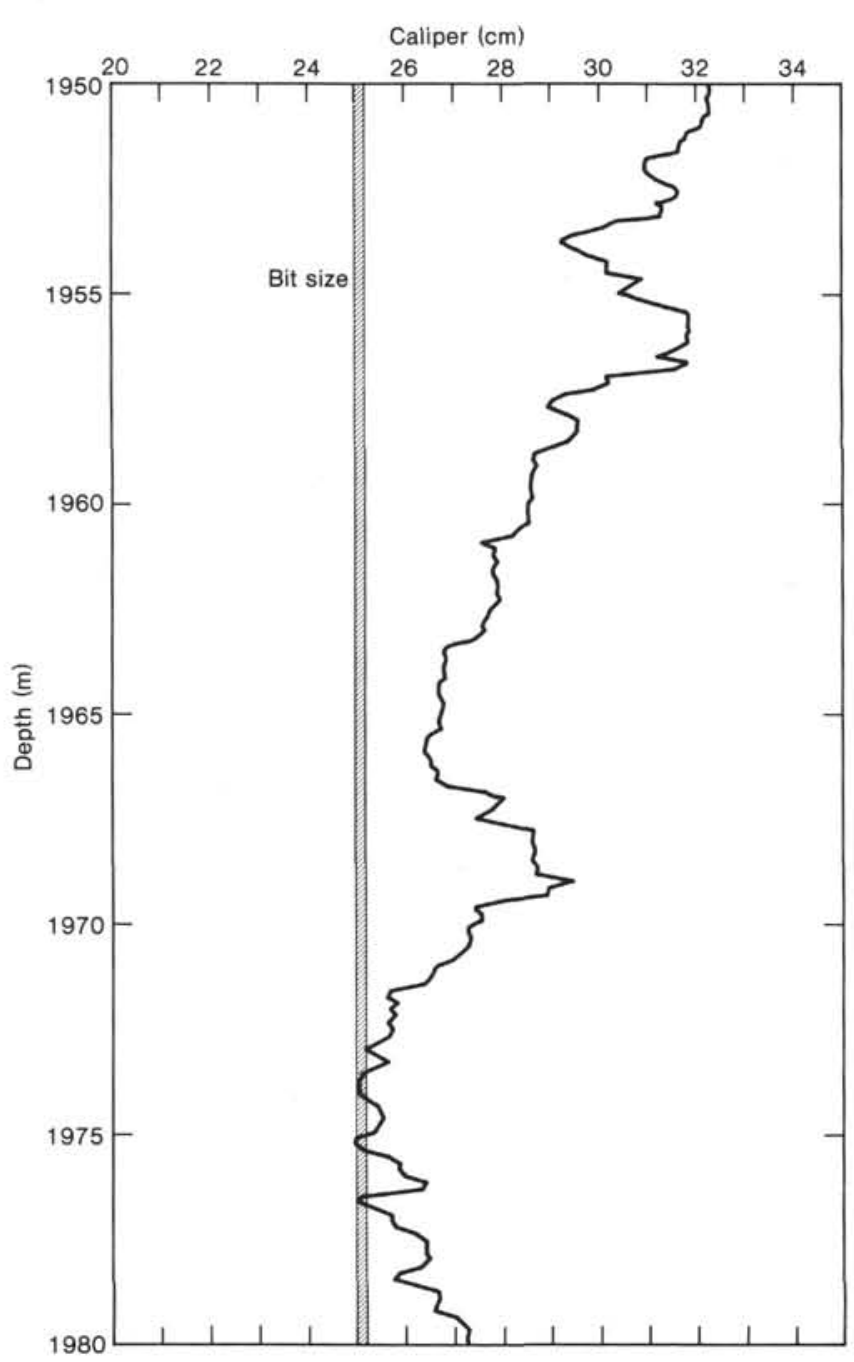

Figure 3. Caliper and bit-size log from 1950 to $1980 \mathrm{~m}$.

with some minor fluctuations in temperature is exhibited through this zone. The temperature log shows temperature equilibrium between the hydrate zone and sediment in Hole 570.

The full-wave sonic log is a record of the sonic wave train recorded by a single detector that is $0.91 \mathrm{~m}$ from the transmitter. The wave train was recorded on film in a wiggle trace display and a variable density display. The full-wave sonic log was not recorded on magnetic tape and is not reproduced in a figure for this section because of data clarity and figure quality. The horizontal scale for both records is from 0.2 to $2.2 \mu \mathrm{s}$. Data were obtained coming up the borehole at a $0.91-\mathrm{m}$ sampling interval. Both records show high travel speed intervals at 1958 to $1975 \mathrm{~m}, 1966$ to $1971 \mathrm{~m}, 1976$ to $1977 \mathrm{~m}$, and 2050 to $2110 \mathrm{~m}$. These intervals correspond to the methane hydrate interval, the nearly pure methane hydrate zone, a limestone stringer, and a major change in lithology (in the last $50 \mathrm{~m}$ of the borehole) from mud, mudstone, and silt to limestone, turbidite sands, and serpentinite, as described from the cores obtained from Hole 570. The full-wave sonic log was not recorded on magnetic tape and, consequently, no data processing was done to this log. The information is only qualitative and will not be used in this report.

The p-wave or $\Delta t$ sonic log is a record of the compressional travel speed versus depth and is recorded in $\mu \mathrm{s} / \mathrm{ft}$. or $\mu \mathrm{s} / \mathrm{m}$. Inverting the travel speed gives values that are called velocity. Velocity is a vector quantity; and the inversion of the travel speed, which is a scaler, produces only a scaler or pseudovelocity. Velocity used in this report is only a scaler measurement and not a true velocity. The sonic, or $\Delta t, \log$ is moderately sensitive to compaction, pore structure, and the degree of interconnection between pores. This measurement is basically a mechanical properties measurement; and, in theory, the normal (compressional or $\mathrm{p}$ ) interval transit time is little affected by the amount of porosity, voids, vugs, or fractures, so long as there is a free solid path (such as solid matrix, ice, or methane hydrate) between transmitter and receivers. The shear wave energy and amplitude, on the other hand, are strongly affected by fractures, voids, and so on. The velocity measurement is influenced more by effective porosity than by total porosity.

The average velocity for most of this borehole is between 1.5 and $2.0 \mathrm{~km} / \mathrm{s}$ (Fig. 1). There are two exceptions to this. One occurs at the last $50 \mathrm{~m}$ of the borehole where the velocity increases to 2.5 to $3.0 \mathrm{~km} / \mathrm{s}$ and indicates a major change in lithology, as previously described. The other exception occurs between 1958.5 and 1973.5 $\mathrm{m}$ where the velocity increases to $3.60 \mathrm{~km} / \mathrm{s}$. This interval defines the methane hydrate layer as shown in Figure 7. Within this layer, another interval between 1965.4 and $1969.4 \mathrm{~m}$ has a nearly constant value of $3.60 \mathrm{~km} / \mathrm{s}$ and outlines the massive methane hydrate zone. A small interval between 1967.4 and $1968.0 \mathrm{~m}$ has a velocity decrease of $0.3 \mathrm{~km} / \mathrm{s}$ or a velocity of $3.3 \mathrm{~km} / \mathrm{s}$. This decrease is probably the result of an impurity in the massive hydrate zone and is probably an inclusion of muddy sediment, as was observed in the recovered hydrate. This $3.60-\mathrm{km} / \mathrm{s}$ velocity is near the value of $3.73 \mathrm{~km} / \mathrm{s}$, which is the velocity of pure methane hydrate (Pearson, 1982; Pearson et al., 1983b). Also, two small peaks or ears are noted on the sonic log at each edge of the 4-m interval (see Fig. 7) of the massive methane hydrate zone (solid gas hydrate was recovered in Core 27 from this interval). This characteristic is seen in other massive hydrate zones (Scott et al., 1980; Mathews, 1982, 1983) and is a feature of the sonic tool and an abrupt velocity change (edge effect). Also, sonic p-wave velocities measured on hydrates formed in Berea sandstone cores increase from 2.5 to $4.5 \mathrm{~km} / \mathrm{s}$ when hydrates begin to form in the pore spaces (Pearson et al., 1983a). Once hydrates form, the velocities reach a plateau where further formation of hydrates produces very little change or increase in the velocity. This plateau characteristic is observed in the 4-m massive hydrate zone between 1965.4 and $1969.4 \mathrm{~m}$.

The sonic log defines a layer that is a mixture of methane hydrates and sediments, and this layer is $15.0 \mathrm{~m}$ thick (1958.5-1973.5 m). Within this layer, a 4-m zone (1965.4-1969.4 m) of massive methane hydrate is observed, as indicated by a velocity plateau of $3.60 \mathrm{~km} / \mathrm{s}$, which is near the $3.73 \mathrm{~km} / \mathrm{s}$ velocity of pure methane hydrate. 


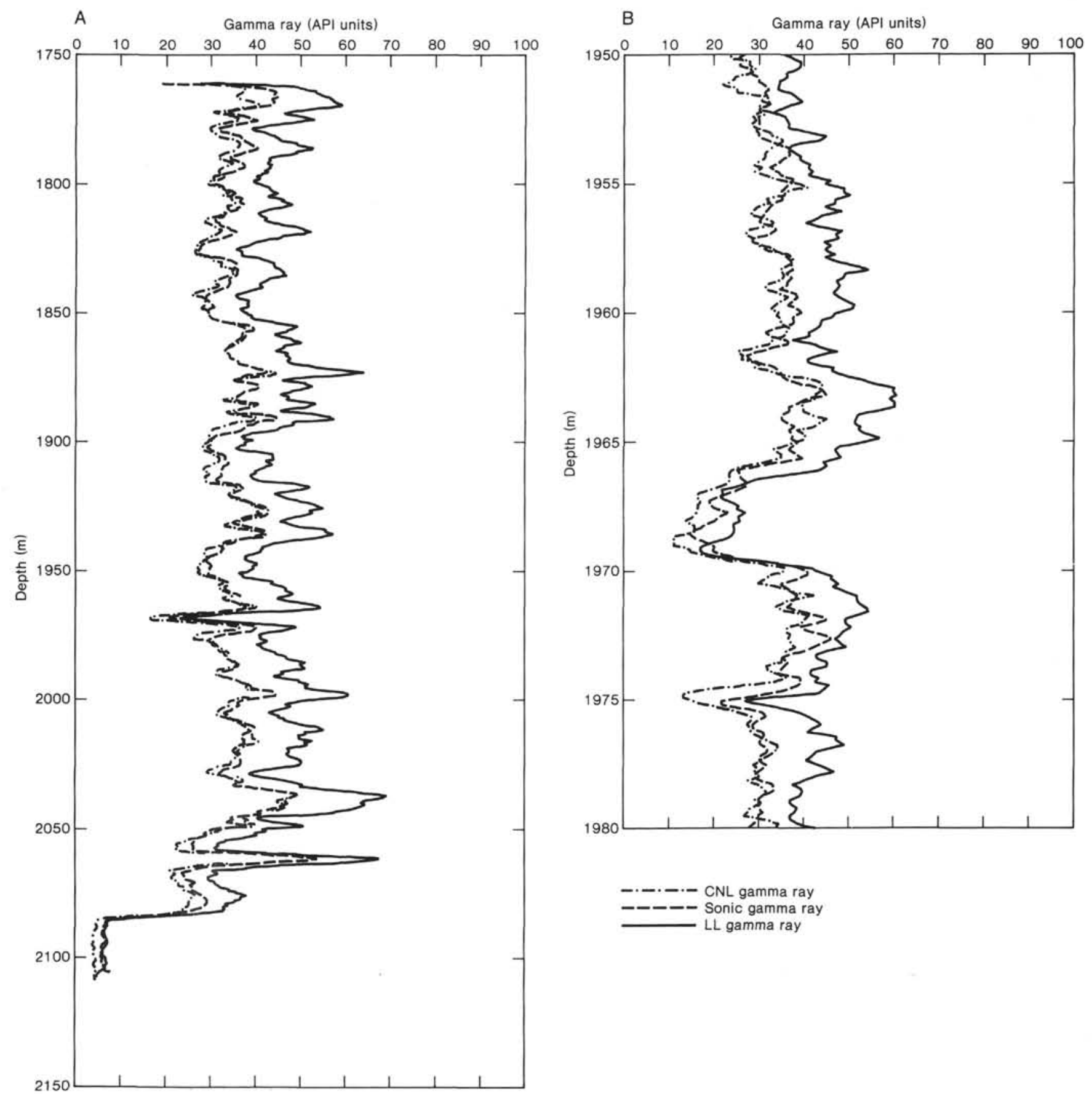

Figure 4. A. Gamma-ray log comparison from 1750 to $2100 \mathrm{~m}$. B. Detailed gamma-ray log comparison from 1950 to $1980 \mathrm{~m}$.

The density log is acquired using a compensated gamma back-scatter tool that has $2 \mathrm{NaI}(\mathrm{Tl})$ scintillation detectors and a ${ }^{137} \mathrm{Cs}$ gamma source, all of which are collimated. The two detectors help compensate for drilling fluid invasion, borehole rugosity, and borehole fluid. This tool responds to electron density, which is converted to bulk density by:

$$
\rho_{\mathrm{b}}=\rho_{\mathrm{e}}\left[\frac{2 \Sigma \mathrm{Z}}{\text { Mol. Wt. }}\right]^{-1}
$$

where $\rho_{\mathrm{b}}=$ bulk density, $\rho_{\mathrm{e}}=$ electron density, $\Sigma Z=$ sum of atomic numbers of atoms making up the molecule, and Mol. Wt. = molecular weight.

The ratio of the sum of atomic numbers to the molecular weight for most formation substances is usually very close to 0.5 , and the bracketed quantity in Equation 1 is very close to unity. Because of this closeness to unity, the electron density and bulk density are assumed equal and the density tool records apparent density directly from electron density. The apparent density is generally assumed to be the bulk density, because correc- 


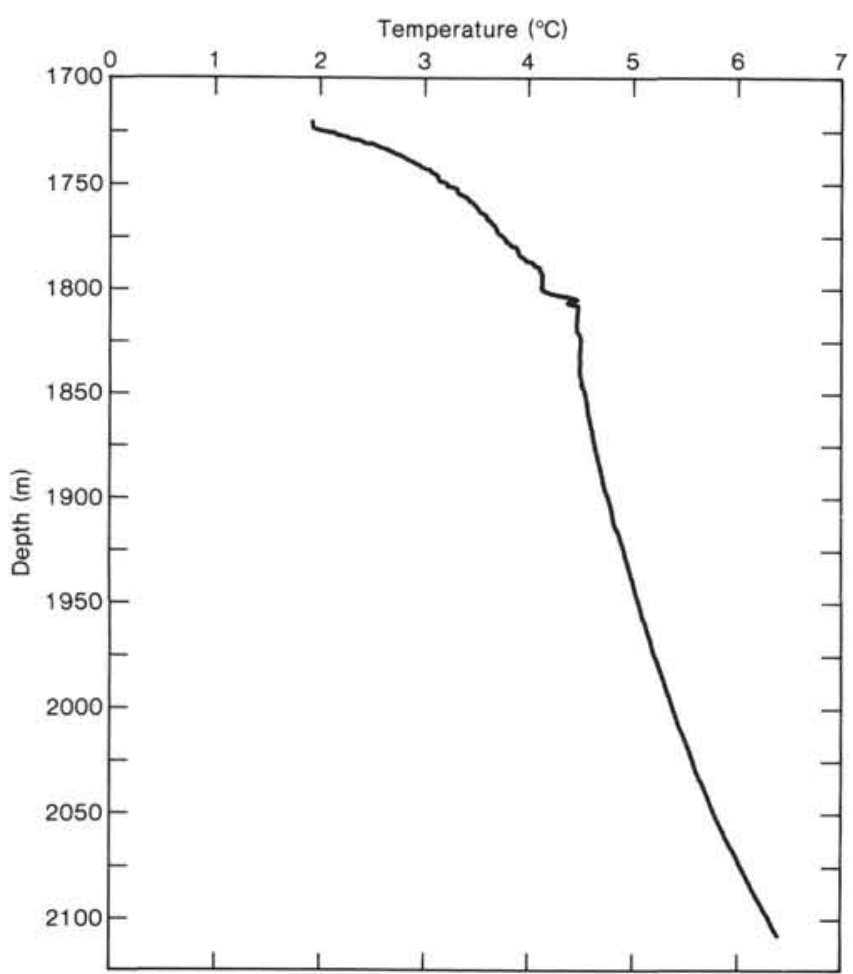

Figure 5. Site 570 temperature log (filtered with 11-point running average).

tions to the electron density are generally small and negligible. Corrections must be made to the apparent density to convert it to true bulk density when the hydrogen element $(\mathrm{Z} / \mathrm{A} \sim 1.0)$ is present as it is in substances such as water, gas, methane hydrate, and other hydrocarbons.

The average density for most of the borehole is approximately $1.75 \mathrm{Mg} / \mathrm{m}^{3}$ (Fig. 1). There are two exceptions to this average value. The first exception occurs at the last $50 \mathrm{~m}$ of the borehole where the density increases to 2.0 to $2.25 \mathrm{Mg} / \mathrm{m}^{3}$ and indicates a major change in lithology as previously described. The other exception occurs between 1958.5 and $1973.5 \mathrm{~m}$ where the density decreases slightly (by $0.1 \mathrm{Mg} / \mathrm{m}^{3}$ ) from the average of 1.75 and decreases substantially between 1966.15 and $1970.15 \mathrm{~m}$ to as low as $1.04 \mathrm{Mg} / \mathrm{m}^{3}$, as shown in Figure 8 . These decreases define the methane hydrate layer and the massive methane hydrate zone that were previously defined by the sonic log. The depth interval for the massive hydrate zone is $0.75 \mathrm{~m}$ deeper than the depth interval defined by the sonic log, and the interval of low density is between 1966.7 and $1969.4 \mathrm{~m}$ or $2.7 \mathrm{~m}$ thick, which is $1.3 \mathrm{~m}$ less in thickness than defined by the sonic log. These differences in depth and thickness probably result from the differences in the two logging tools. The density tool is a volume statistical measurement with a small depth of investigation. The sonic tool has a somewhat deeper depth of investigation and is basically a mechanical properties or molecular measurement. The density data do not show a variation in density for the small interval of 1967.4 to $1968.0 \mathrm{~m}$ where the velocity

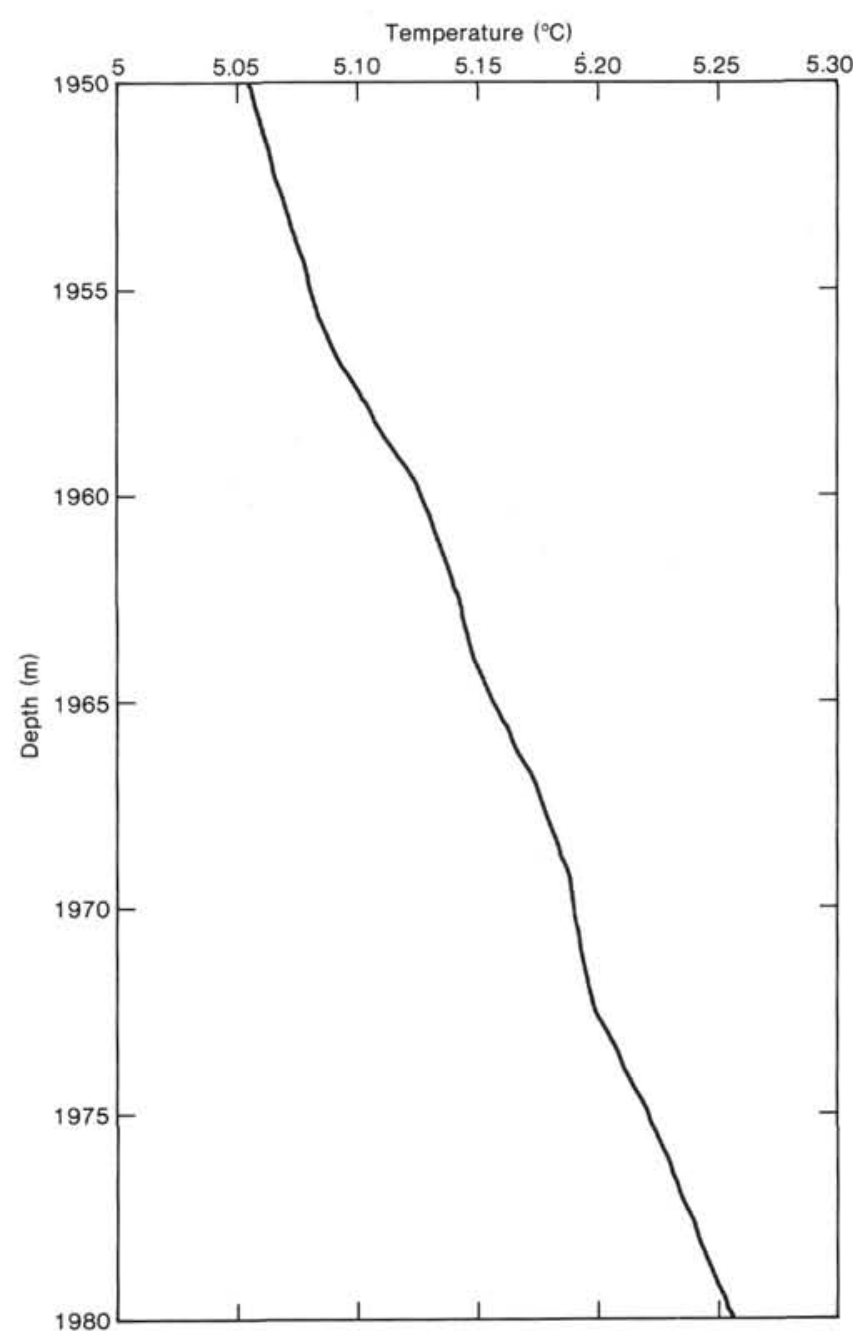

Figure 6. Detailed temperature log (filtered with 11-point running average) from 1950 to $1980 \mathrm{~m}$.

data show a small decrease in velocity because of an inclusion of sediment.

The density measured between 1966.7 and $1969.4 \mathrm{~m}$ needs to be corrected for the presence of methane. The apparent density for this interval is between 1.04 and $1.06 \mathrm{Mg} / \mathrm{m}^{3}$. This apparent density $\left(\rho_{\mathrm{a}}\right)$ as seen by the density tool is related to the true bulk density $\left(\rho_{\mathrm{b}}\right)$ as defined by Schlumberger (1972):

$$
\rho_{\mathrm{a}}=1.335 \rho_{\mathrm{b}}-0.188
$$

This equation corrects for the presence of hydrogen and the term

$$
\frac{2 \Sigma Z}{\text { Mol. Wt. }}
$$

in Equation 1. Rearranging Equation 2 gives:

$$
\rho_{\mathrm{b}}=0.749 \rho_{\mathrm{a}}+0.141
$$

The apparent values of density are corrected using Equation 3 , giving the true bulk density. The following table 


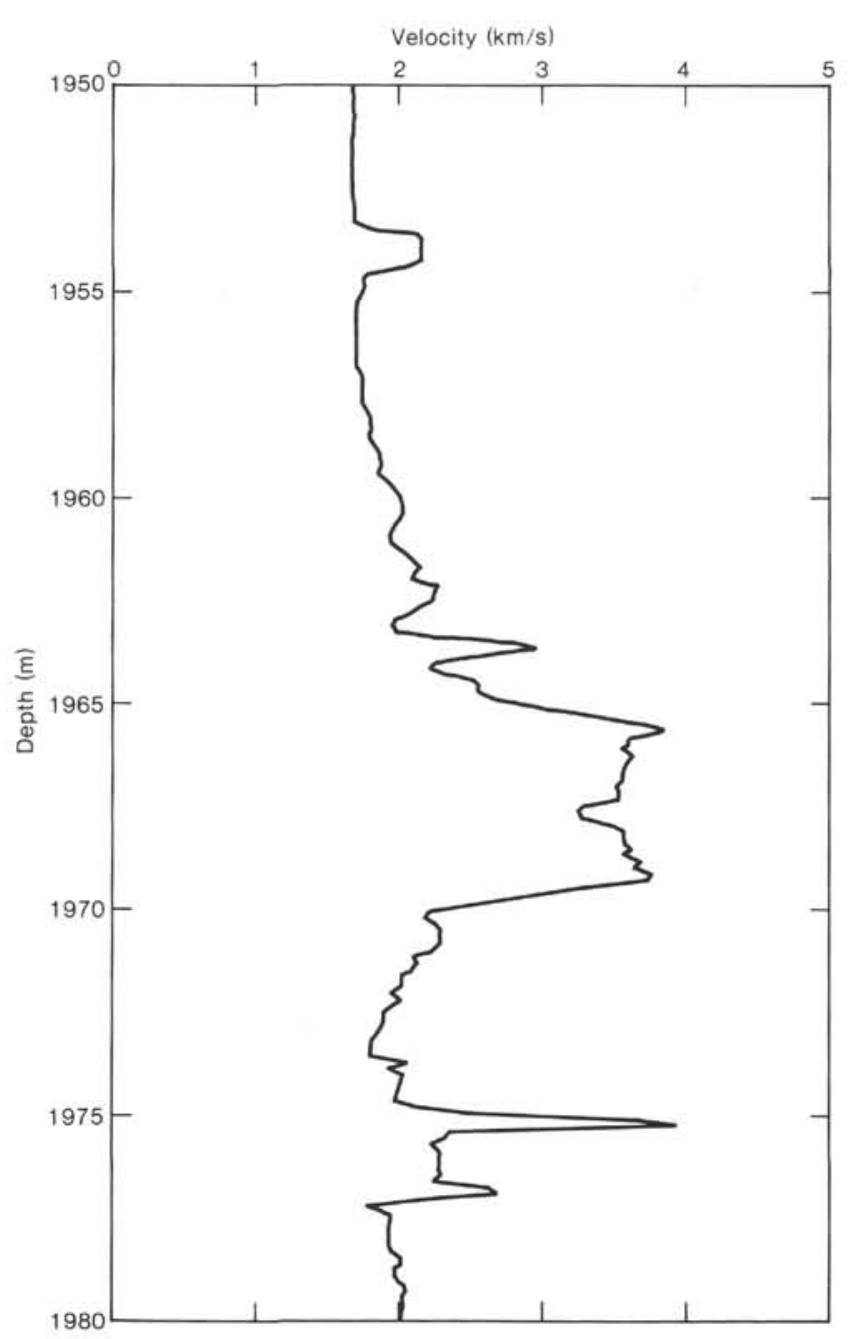

Figure 7. Velocity data from 1950 to $1980 \mathrm{~m}$.

lists the corrected density for the massive methane hydrate zone:

\begin{tabular}{cc}
\hline $\begin{array}{c}\text { Apparent density } \\
\left(\mathrm{Mg} / \mathrm{m}^{3}\right)\end{array}$ & $\begin{array}{c}\text { True bulk density } \\
\left(\mathrm{Mg} / \mathrm{m}^{3}\right)\end{array}$ \\
\hline 1.06 & 0.93 \\
1.04 & 0.92 \\
\hline
\end{tabular}

These true bulk density are the same values reported for pure methane hydrate $\left(100 \%\right.$ methane, $\mathrm{CH}_{4}$ gas only) by Scott et al. (1980), Makogen et al. (1971), and Pearson (1982).

This extremely low density for the massive methane hydrate zone was not observed in other massive methane hydrates (Scott et al., 1980; Mathews, 1982, 1983), which were mixtures of sand and sandstone that had their pores almost completely filled with methane hydrate. This lowdensity characteristic probably indicates an almost pure methane hydrate zone.

Resistivity data were obtained using the dual laterolog, which has two laterologs called LLd and LLs. The LLd (deep laterolog) has longer bucking electrodes and spacing and, consequently, a deeper depth of investiga-

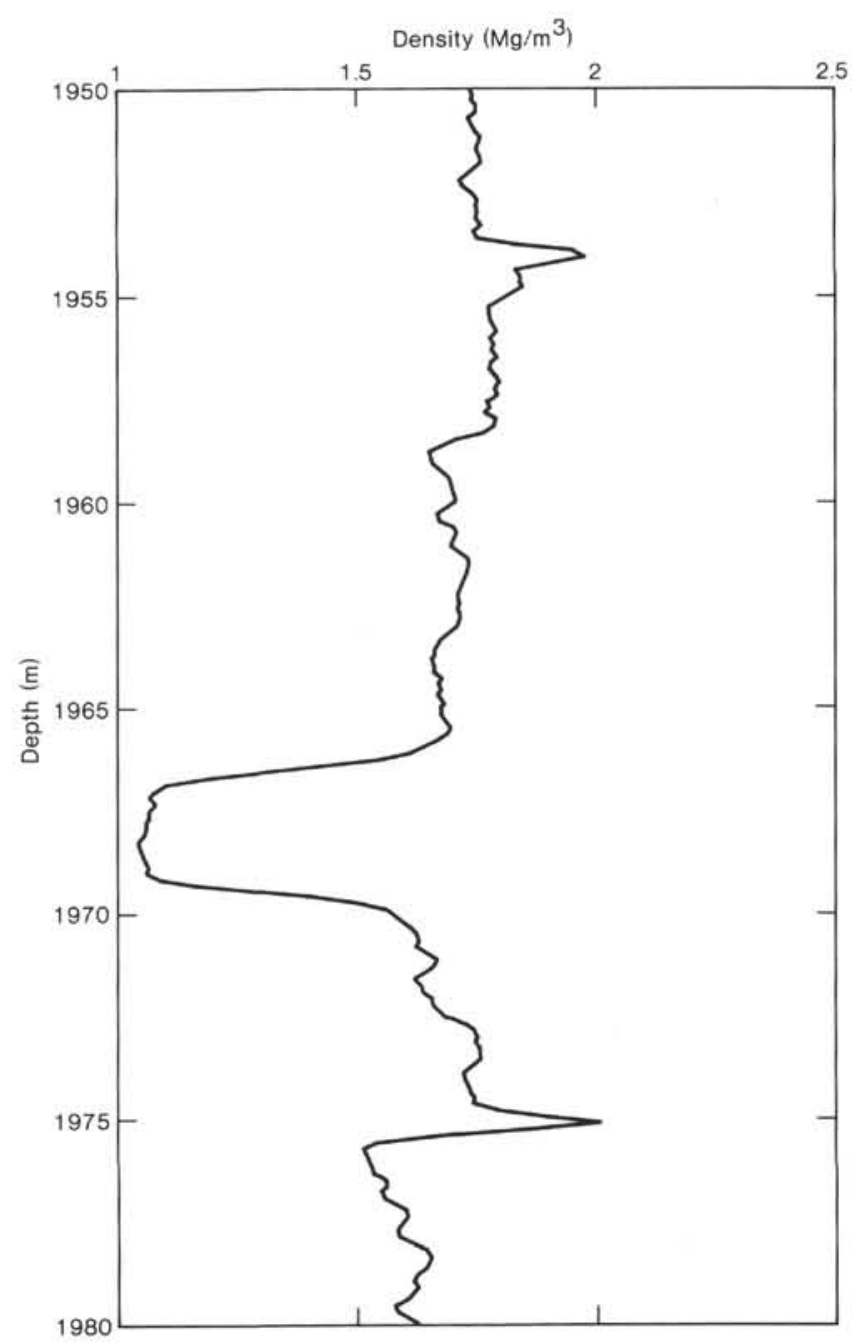

Figure 8. Density data from 1950 to $1980 \mathrm{~m}$.

tion than the companion LLs (shallow laterolog), which has a shallower depth of penetration. Both laterologs have current beam thicknesses of $61 \mathrm{~cm}$. These devices can be significantly affected by the borehole size, the borehole mud, the invaded zone, and adjacent beds. The borehole mud in Hole 570 was seawater, which is conductive and has a negligible effect. Also, the conate water and the drilling fluid are similar, and the invaded zone correction can be ignored. The only corrections needed for the LLd and LLs are the borehole and bedthickness corrections.

Laterolog devices are very sensitive to pore structure and their interconnection. A continuous water-filled pore structure short-circuits the current lines and lowers the resistivity readings. But in a low porosity, the conductivity network is generally very small and increases the apparent resistivity. Another way to increase the apparent resistivity is to change the fluid in the pore structure from conductive seawater (or nearly seawater) to hydrocarbons (oil and gas), ice, or a combination of hydrocarbons and ice (methane hydrate). Any of these changes would cause large increases in the resistivity readings. The laterolog tool works well in conductive borehole mud (seawater) and in a high-resistivity environment. 
The average resistivity for most of the borehole is 2 to $3 \mathrm{ohm}-\mathrm{m}$ for the LLd and 1 to $2 \mathrm{ohm}-\mathrm{m}$ for the LLs. There are two exceptions to these average resistivities, and they both occur at the same depths for both laterologs. The first exception occurs in the last $50 \mathrm{~m}$ of the borehole where the resistivity for both tools increases to 5 to $10 \mathrm{ohm}-\mathrm{m}$, except for the interval of 2084 to $2090 \mathrm{~m}$ (Fig. 1). In this interval, the LLd has a resistivity of $0.6 \mathrm{ohm}-\mathrm{m}$, and the LLs has a resistivity of $0.3 \mathrm{ohm}-\mathrm{m}$. The increase in resistivity for the last $50 \mathrm{~m}$ of the borehole indicates a major change in lithology as previously described. The low-resistivity interval $(2084-2090 \mathrm{~m})$ is probably caused by a conductive clay or mud layer. This puzzling low-resistivity interval is not well understood.

The other exception to these average resistivities occurs in the interval between 1965 and $1970 \mathrm{~m}$ where the resistivity increases to $150 \mathrm{ohm}-\mathrm{m}$ for both laterologs, as shown in Figure 9. This increase in resistivity is 100 to 150 times greater than the average resistivity for most of the borehole. This resistivity increase correlates with the velocity increase and the density decrease and defines the massive methane hydrate zone.

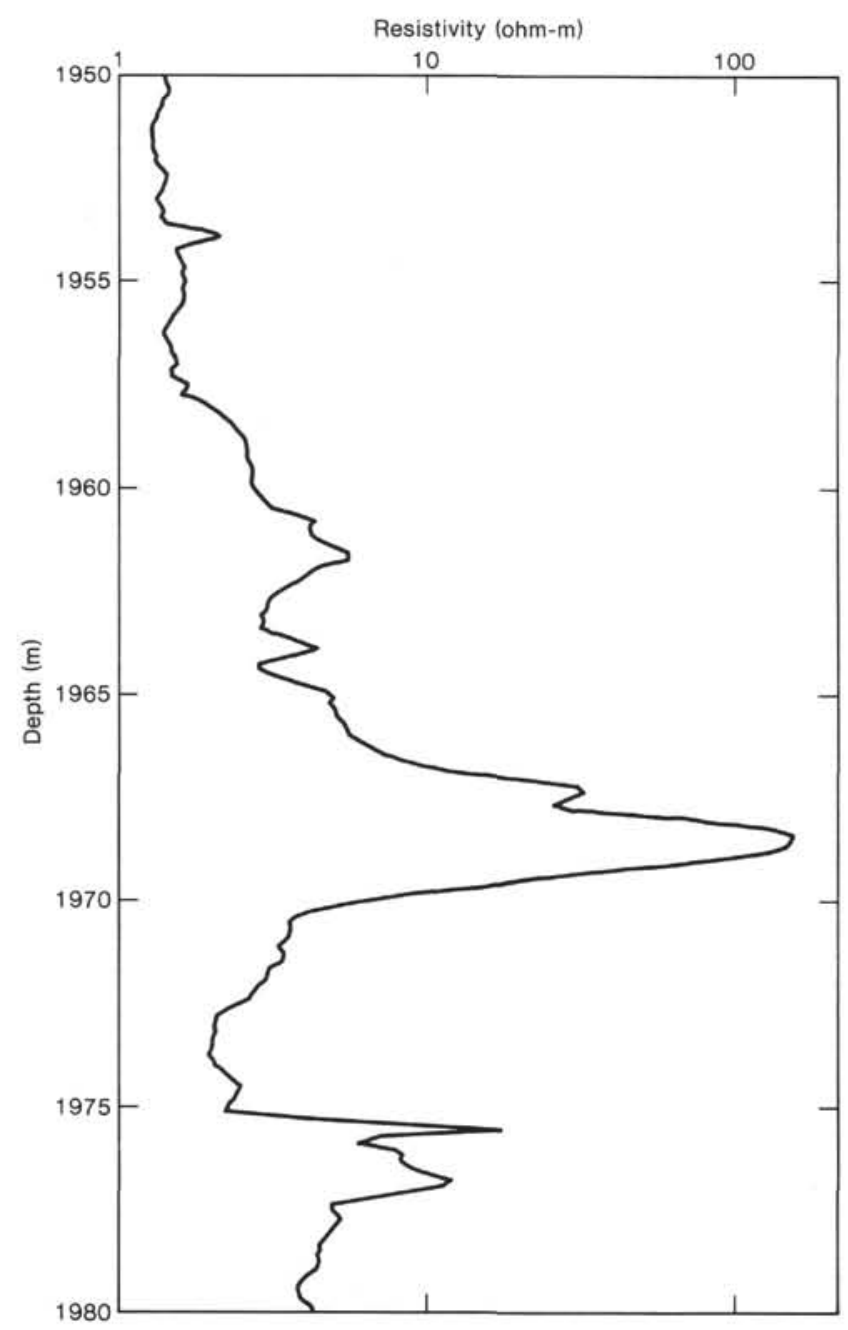

Figure 9. Resistivity data (both LLd and LLs) from 1950 to $1980 \mathrm{~m}$.
There are no reported laboratory resistivity measurements on hydrate-containing sediments. Because hydrates are electrical insulators, the resistivities of hydrate deposits are largely controlled by the unfrozen brine inclusions. The resistivity of a Berea sandstone core increased by an order of magnitude and continued to increase rapidly as further increases in hydrate reduced the unfrozen brine present in the core (Pearson et al., 1983b). The resistivity anomaly seen on both laterologs shows an increase in resistivity from the average resistivity of most of the borehole. This increase is by two orders of magnitude and indicates an almost pure layer of methane hydrate.

Earlier it was stated that laterologs must be corrected for borehole and bed-thickness effects. When these corrections are made, the maximum resistivity for the LLs $\log$ is $154 \mathrm{ohm}-\mathrm{m}$ (corrected laterolog resistivities are expressed as clls; see Fig. 10), and the maximum resistivity for the LLd log is $175 \mathrm{ohm}-\mathrm{m}$ (clld; see Fig. 11). This difference results from the different depth of investigation of the laterolog tools because the current of a later-

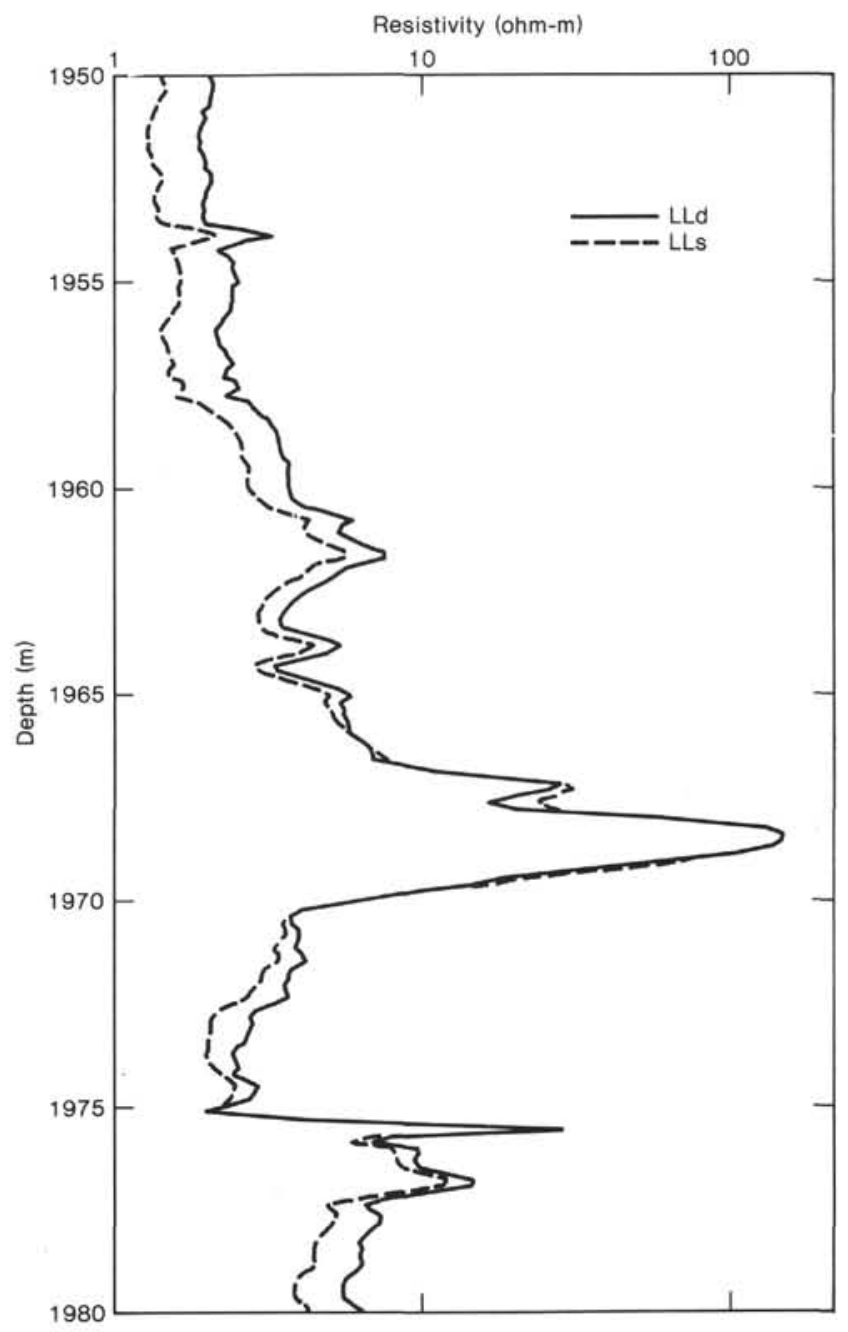

Figure 10. Corrected laterolog shallow (clls) resistivity data from 1950 to $1980 \mathrm{~m}$. 


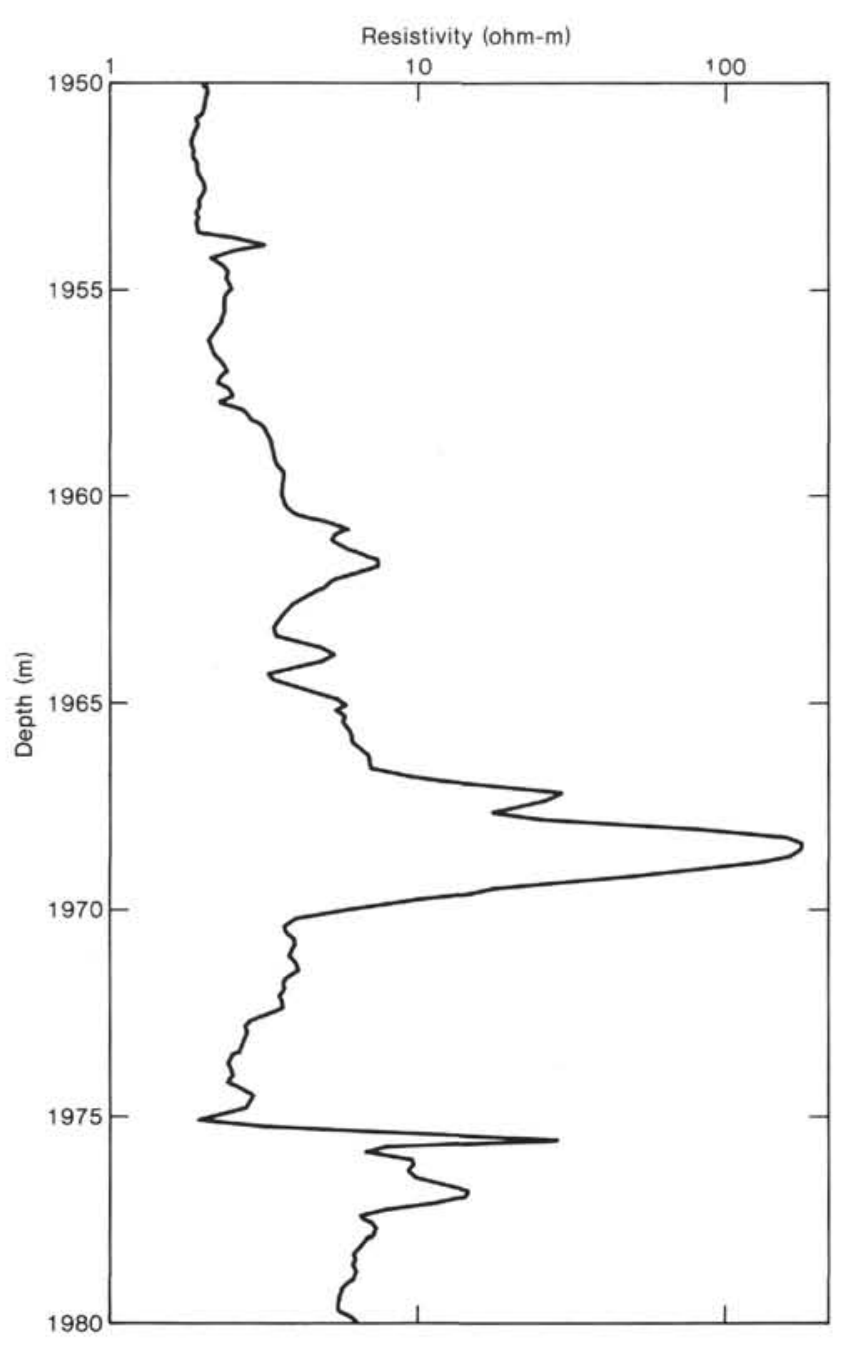

Figure 11. Corrected laterolog deep (clld) resistivity data from 1950 to $1980 \mathrm{~m}$.

olog has to traverse mud and invaded zone to reach the undisturbed formation. The LLd has a deeper depth of investigation and measures more of the undisturbed formation than does the LLs. The small amount of drilling fluid (seawater) invasion in the hydrate zone is thought to produce this difference in maximum resistivities. The shape of the resistivity curves flattens out and nearly plateaus at these maximum resistivities, indicating an almost pure methane hydrate zone at these maximum resistivities, and this characteristic is seen in other massive hydrate zones (Scott et al., 1980; Mathews, 1982, 1983). This fact will be used in estimating the amount of methane hydrate in a later section.

A compensated neutron porosity log was obtained for Hole 570. This log is scaled in limestone porosity units and shows an average porosity of 50 to $60 \%$ for most of the borehole (Fig. 1). Two exceptions are again noted. The first exception occurs in the lower $50 \mathrm{~m}$ of the borehole where the porosity decreases to 40 to $50 \%$ and then increases to 55 to $60 \%$ from $2084 \mathrm{~m}$ to TD. The porosity decrease indicates a major change in lithology, as previously described. The increase in porosity at
$2084 \mathrm{~m}$ correlates at the same depth with the laterolog decrease in resistivity previously described.

The second exception occurs at a depth interval of 1966 to $1970 \mathrm{~m}$. Here, the average porosity increases from approximately 55 to $70 \%$ for this $4-m$ interval and corresponds to the previously identified massive methane hydrate zone (see Fig. 12). The increase in scaled porosity is a result of the increase in hydrogen and carbon from the methane and, to a small extent, the decrease in density previously described. Again, the neutron tool measures the increased hydrogen from the methane hydrate as though it has encountered a water-saturated limestone rock with increased porosity. This characteristic was not observed in other massive hydrates (Scott et al., 1980; Mathews, 1982, 1983), which were mixtures of sand or sandstone that had their pores almost completely filled with methane hydrate. This neutron-porosity increase characteristic probably indicates an almost pure methane hydrate zone.

Three gamma-ray logs were obtained for Hole 570 . These logs were previously described in the introduction,

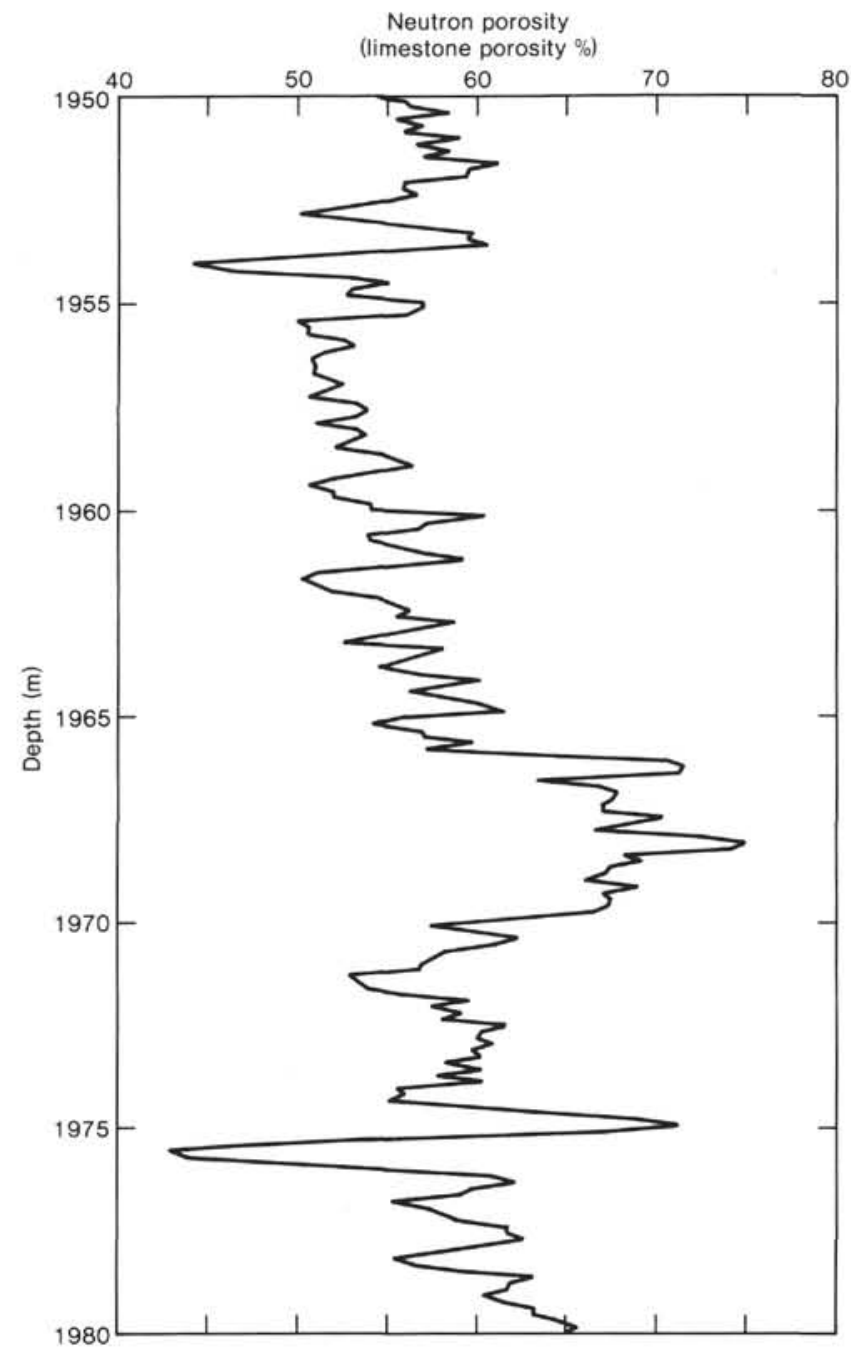

Figure 12. Neutron porosity (limestone porosity units) from 1950 to $1980 \mathrm{~m}$. 
where depth discrepancies between log runs (a separate gamma-ray log was obtained for each log run) were determined as negligible (Fig. 4). The gamma-ray log is a measurement of the natural radioactivity from the elements of potassium, thorium series, and the uraniumradium series that are in the formations. This log can be used to distinguish sands from shales in sedimentary formations and to distinguish major changes in lithology. The general character of this log indicates a shale or mudstone environment with some small intervals of shaly sand and limestone stringers.

There are two intervals that show a marked decrease in radioactivity. The first interval is between 1965 and $1970 \mathrm{~m}$ (Fig. 4A and B) and corresponds to the massive hydrate zone. One explanation is that the hydrate zone has been formed in a void of a fault zone, or crack, that has increased in volume because of tectonic movement. The radioactive elements were not included or deposited during methane hydrate formation.

The second interval is from $2084 \mathrm{~m}$ to the bottom of Hole 570. The API units for this interval are very low (4-8 API units) and indicate a major change in lithology, as previously described.

\section{IMPEDANCE LOGS CALCULATED FOR HOLE 570}

The impedance log for Hole 570 is the combination of the velocity and density data. A plot of the impedance $\log \left(\mathrm{Mg} \cdot \mathrm{km} / \mathrm{s} \cdot \mathrm{m}^{3}\right)$ along with the velocity $\log$ $(\mathrm{km} / \mathrm{s})$ and the density $\log \left(\mathrm{Mg} / \mathrm{m}^{3}\right)$ is shown in Figure 13 for the depth interval of 1950 to $1980 \mathrm{~m}$. This interval includes the previously identified methane hydrate layer from 1958.5 to $1973.5 \mathrm{~m}$, the previously identified massive methane hydrate zone of 1965.4 to $1969.4 \mathrm{~m}$, and a limestone or dolomite stringer (Core 27) at $1975 \mathrm{~m}$. A thin 1-m impedance anomaly, where the maximum impedance is $6.5 \mathrm{Mg} \cdot \mathrm{km} / \mathrm{s} \cdot \mathrm{m}^{3}$, is seen at the top of the massive methane hydrate zone $(1966 \mathrm{~m})$. The base of the massive methane hydrate zone, as well as the top and base of the hydrate layer, show only a small or negligible increase in impedance. A thin (less than $0.5-\mathrm{m}$ ) impedance layer, where the maximum impedance is $7.3 \mathrm{Mg}$. $\mathrm{km} / \mathrm{s} \cdot \mathrm{m}^{3}$, is also seen to correlate with the limestone or dolomite stringer at $1975 \mathrm{~m}$. These impedance layers are too thin to produce anomalous seismic reflections in seismic records, as seen elsewhere off Guatemala (Ladd et al., 1982; von Huene et al., 1982; Shipley et al., 1982) on the Blake Outer Ridge and offshore Nicaragua (Macleod, 1982). Anomalous reflections seen on seismic profiles in these areas have been interpreted as the base of gas hydrate layers (BSR). At Site 570, no impedance anomaly exists in the massive hydrate; and the base of the methane hydrate layer is at a level below the base of the sediment.

Another way of analyzing the impedance, velocity, and density data for the 1950 to $1980 \mathrm{~m}$ interval is to look at the normalized impedance, velocity, and density data, as shown in Figure 14. Throughout most of the methane hydrate layer (1958.5-1973.5 m), whenever the normalized velocity increases, the corresponding normalized density decreases and this combination yields a

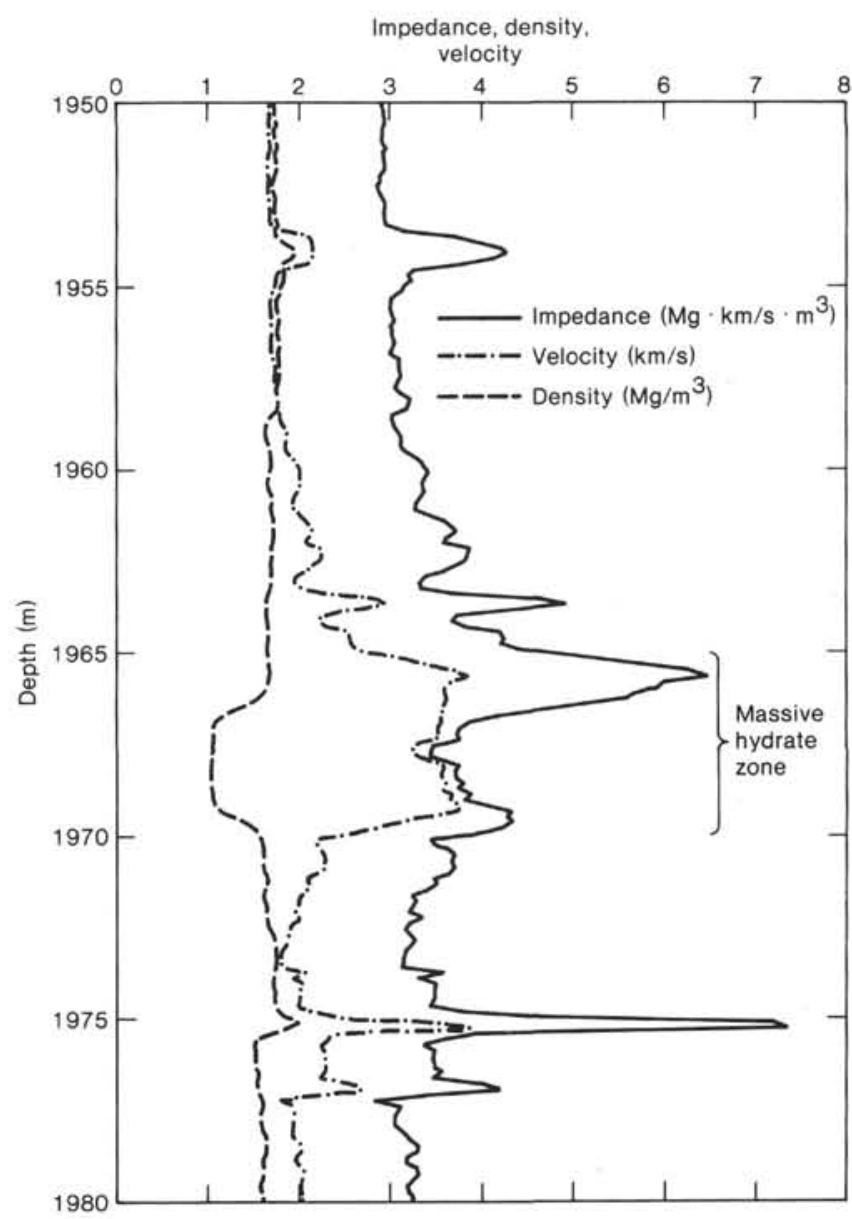

Figure 13. Comparison of impedance, density, and velocity data from 1950 to $1980 \mathrm{~m}$.

normalized impedance of 0.4 to 0.5 . The same phenomenon occurs throughout most of the massive methane hydrate zone (1965.4-1969.4 m). The exception occurs at the top of this zone where the normalized velocity increases but the corresponding normalized density does not decrease. This exception yields the thin normalized anomaly at the top of the massive methane hydrate zone that was previously mentioned. On the other hand, the thin limestone or dolomite stringer $(1975 \mathrm{~m})$ has a normalized velocity and density increase, and this combination yields a maximum normalized impedance of 1 .

If the normalized resistivity data describe the hydrate purity, then plotting the normalized resistivity from the corrected laterolog shallow (clls) with the normalized impedance, density, and velocity (see Fig. 15) shows that the impedance anomaly does not correlate with the resistivity anomaly. There is approximately a $3-\mathrm{m}$ separation between these anomalies. Also, plotting the normalized resistivity from the corrected laterolog deep (clld) with the normalized impedance, density, and velocity (see Fig. 16) shows that the impedance anomaly again does not correlate with the resistivity anomaly. There is approximately a 3-m separation between these anomalies. The resistivity anomalies from the clls and clld occur within the velocity and density outlines of the massive methane hydrate zone, and they both occur at the 


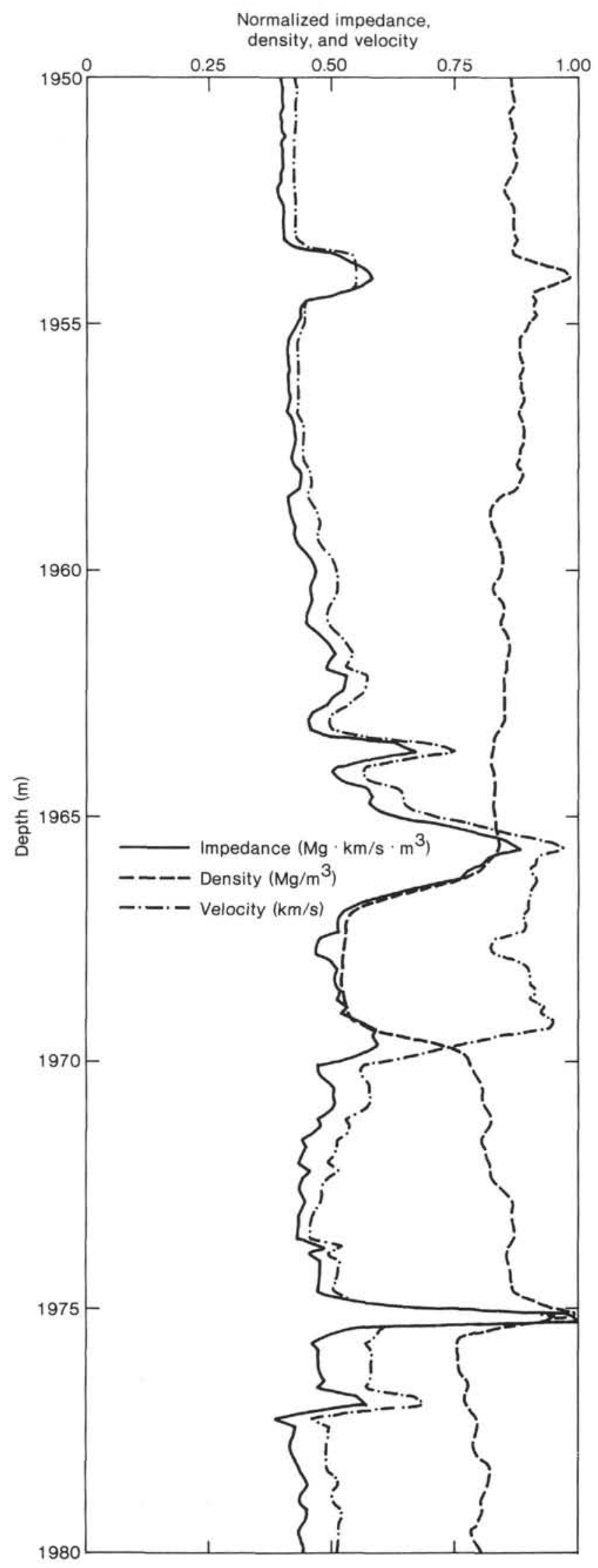

Figure 14. Comparison of normalized impedance, density, and velocity data from 1950 to $1980 \mathrm{~m}$.

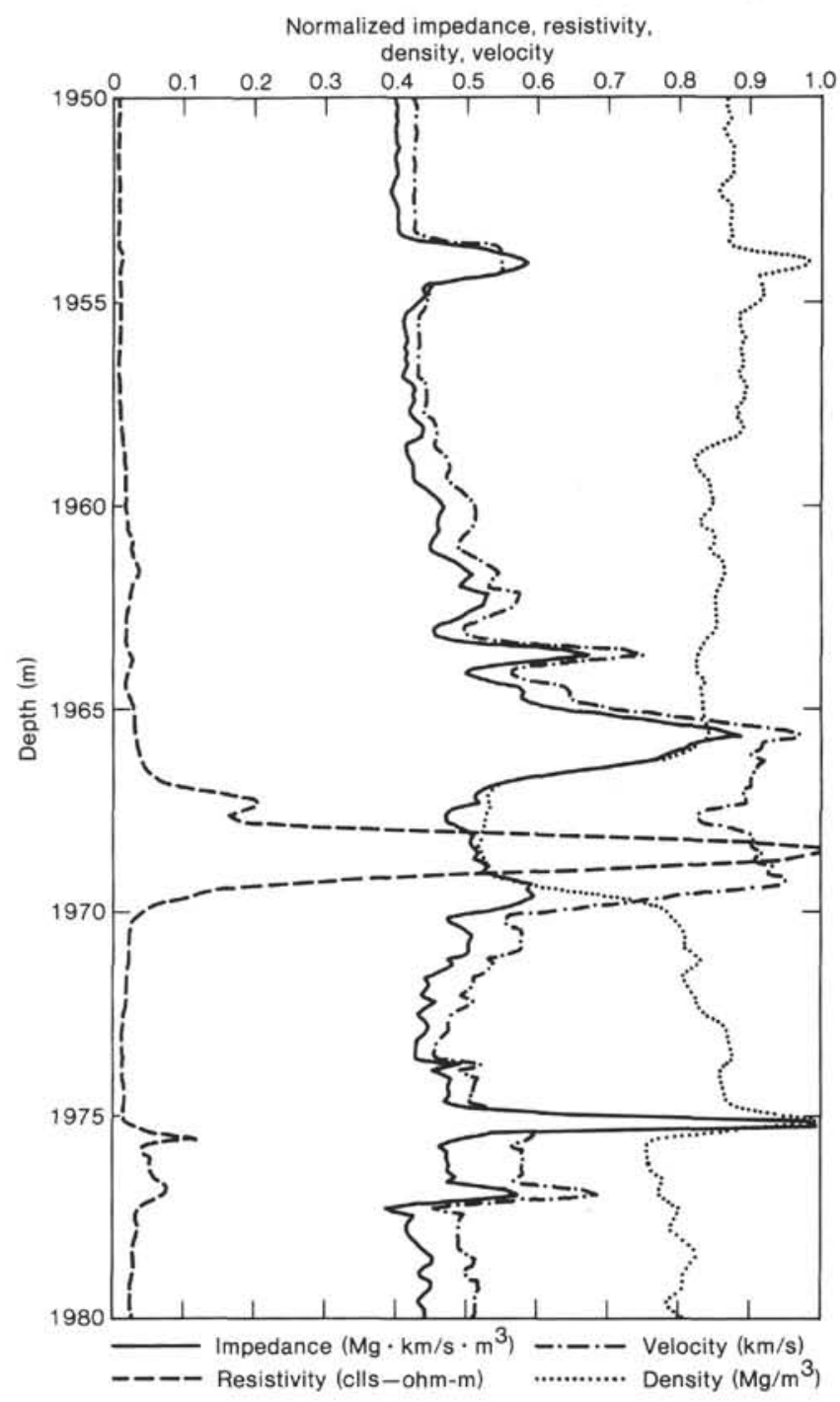

Figure 15. Comparison of normalized impedance, density, velocity and resistivity (clls) data from 1950 to $1980 \mathrm{~m}$.

bottom of this zone where no impedance anomaly exists. Consequently, there is no impedance anomaly at the base of the massive methane hydrate zone nor at the base of the methane hydrate layer, and no anomalous reflections are seen on the seismic records in the Site 570 site surveys. These observations indicate that (1) the Site 570 methane hydrate area is different from the Blake Outer Ridge and other methane hydrate areas; and (2) the high resistivity layer observed on the clld and clls is within the density and velocity data that identify the massive methane hydrate zone, but this resistivity layer is not associated with an impedance anomaly.

\section{INTERPRETATION AND METHANE CONTENT ESTIMATE}

In this section, the methane hydrate layer identified from various well logs and the massive methane hydrate zone as described in Core 27 are analyzed. Cross-plot data of resistivity versus velocity from the methane hy- 


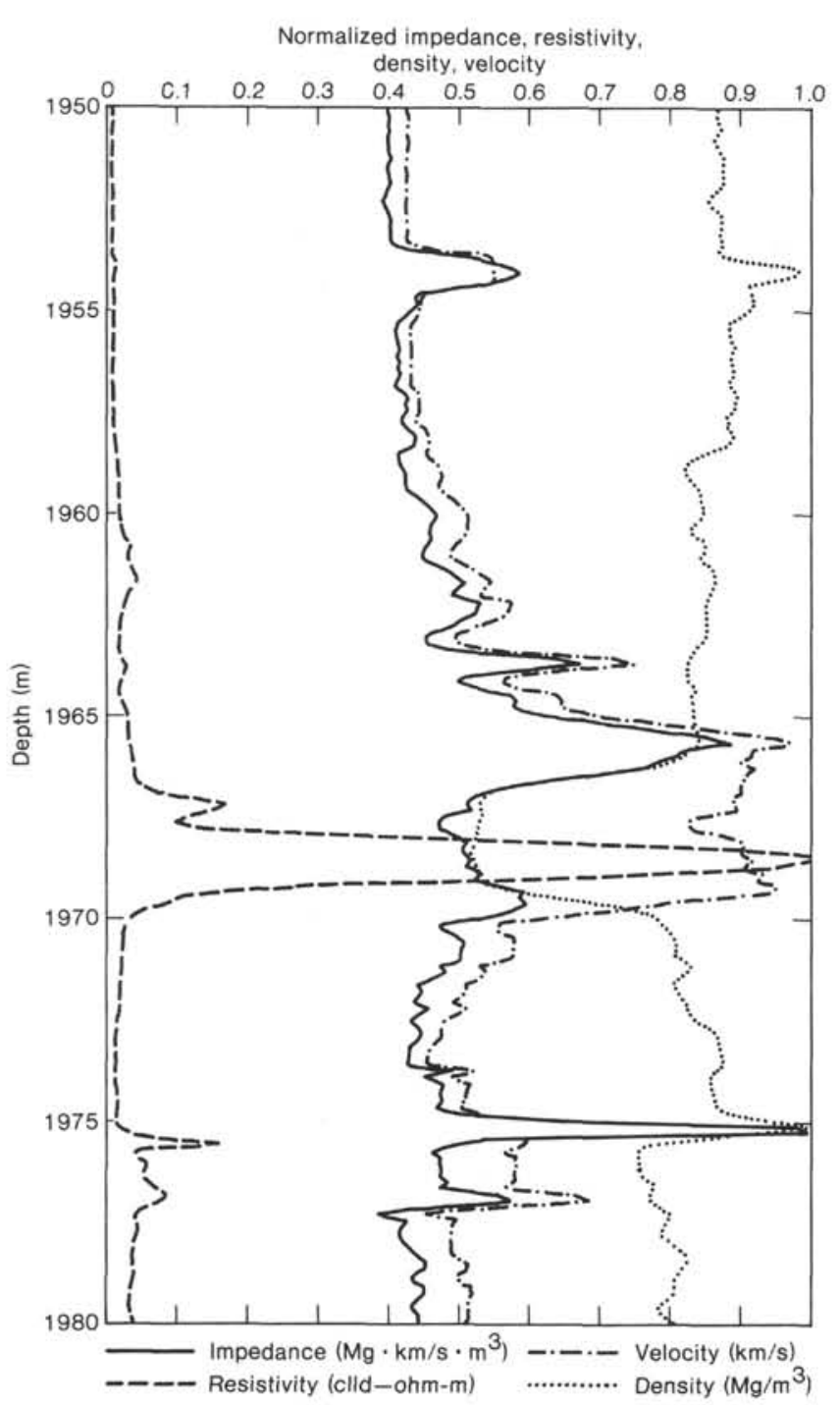

Figure 16. Comparison of normalized impedance, density, velocity and resistivity (clld) data from 1950 to $1980 \mathrm{~m}$.

drate layer and massive methane hydrate zone are shown and analyzed. Finally, an estimate of methane gas content was made using a $R_{t}$ normalization technique that employs the true resistivities obtained from the clld and clls logs.

The methane hydrate layer and the massive methane hydrate zone were identified either completely or partially in the log data description section. Table 1 lists the log data and whether or not they define any of the hydrates encountered in Hole 570.

The methane hydrate layer is anomalous on five of the ten logs acquired ( $p$-wave sonic, full-wave sonic, density, and two laterolog resistivities) and the massive methane hydrate zone is anomalous on seven of the ten logs acquired (p-wave sonic, full-wave sonic, density, two laterolog resistivities, gamma-ray, and neutron porosity).

The average log properties and matrix and fluid values for Hole 570 are listed in Table 2.

The matrix velocity $[2.05 \mathrm{~km} / \mathrm{s}(148.7 \mu \mathrm{s} / \mathrm{ft}$.) $]$ was calculated using the neutron $\left(\phi_{\mathrm{N}}\right)$ and calculated density $\left(\phi_{\mathrm{D}}\right)$ porosity of $56.25 \%$ from the 1875 to $1950 \mathrm{~m}$ inter-
Table 1. Hydrate defined by log response.

\begin{tabular}{|c|c|c|}
\hline Log data & $\begin{array}{l}\text { Methane hydrate layer } \\
(1958.5-1973.5 \mathrm{~m})\end{array}$ & $\begin{array}{c}\text { Massive methane } \\
\text { hydrate zone } \\
(1965.4-1969.4 \mathrm{~m})\end{array}$ \\
\hline p-wave sonic & Defines layer & Defines zone $-4 \mathrm{~m}$ thick \\
\hline Density & Defines layer & Defines zone- $2.7 \mathrm{~m}$ thick \\
\hline Resistivity & $\begin{array}{l}\text { Both LLs and LLd } \\
\text { define layer }\end{array}$ & $\begin{array}{l}\text { Both LLs and LLd define } \\
\text { zone-0.6 m deeper }\end{array}$ \\
\hline Full-wave sonic & $\begin{array}{l}\text { Wiggle trace defines } \\
\text { variable density defines }\end{array}$ & $\begin{array}{l}\text { Wiggle trace defines } \\
\text { variable density defines }\end{array}$ \\
\hline Gamma-ray & Does not define layer & Defines zone $-0.5 \mathrm{~m}$ deeper \\
\hline Neutron porosity & Does not define layer & Defines zone- $0.5 \mathrm{~m}$ deeper \\
\hline SP & Does not define layer & Does not define zone \\
\hline Caliper & Does not define layer & Does not define zone \\
\hline Temperature & Does not define layer & Does not define zone \\
\hline
\end{tabular}

Table 2. Hole 570 matrix, fluid, and average log properties.

\begin{tabular}{llll}
\hline \multicolumn{1}{c}{ Log type } & \multicolumn{1}{c}{ Average } & \multicolumn{1}{c}{ Matrix } & \multicolumn{1}{c}{ Fluid } \\
\hline Velocity $(\Delta \mathrm{t})$ & $1.5-2.0 \mathrm{~km} / \mathrm{s}$ & $2.05 \mathrm{~km} / \mathrm{s}(148.7 \mu \mathrm{s} / \mathrm{ft}$.) & $1.5 \mathrm{~km} / \mathrm{s}(203.3 \mu \mathrm{s} / \mathrm{ft}$.) \\
Density & $1.75 \mathrm{Mg} / \mathrm{m}^{3}$ & $2.65 \mathrm{Mg} / \mathrm{m}^{3}$ & $1.05 \mathrm{Mg} / \mathrm{m}^{3}$ \\
Resistivity & & & \\
$\quad$ LL.d & $2-3 \mathrm{ohm}-\mathrm{m}$ & & $0.25-0.30 \mathrm{ohm}-\mathrm{m}$ \\
$\quad$ LLs & $1-2 \mathrm{ohm}-\mathrm{m}$ & & $0.25-0.30 \mathrm{ohm}-\mathrm{m}$ \\
Neutron porosity & $50-65 \%$ limestone & & \\
\hline
\end{tabular}

val, a fluid velocity of $1.5 \mathrm{~km} / \mathrm{s}(203.3 \mu \mathrm{s} / \mathrm{ft}$.), and a log velocity of $1.7 \mathrm{~km} / \mathrm{s}(179.3 \mu \mathrm{s} / \mathrm{s})$. The $\phi_{\mathrm{D}}$ is determined from

$$
\phi_{\mathrm{D}}=\frac{\rho_{\mathrm{b}}-\rho_{\mathrm{m}}}{\rho_{\mathrm{f}}-\rho_{\mathrm{m}}}
$$

where $\phi_{\mathrm{D}}=$ density porosity; $\rho_{\mathrm{b}}=$ bulk density from $\log ; \rho_{\mathrm{m}}=$ matrix density; and $\rho_{\mathrm{f}}=$ fluid density.

These are low matrix and log velocities. These low velocity values result from unconsolidated and poorly compacted mud and mudstones. The overburden to formation fluid pressure differentials must be greater than 27.5 to $34.5 \mathrm{MPa}$ (4000 to $5000 \mathrm{psi}$ ) in order to obtain sufficiently compacted sediments to use Wyllie's time average equation (Wyllie et al., 1956 and 1958) to calculate porosity from the sonic log. This equation is:

$$
\phi_{\Delta t}=\frac{\Delta t_{l o g}-\Delta t_{m}}{\Delta t_{f}-\Delta t_{m}}
$$

where $\phi_{\Delta t}=$ porosity calculated from sonic log traveltime; $\Delta \mathrm{t}_{\mathrm{m}}=$ matrix traveltime; $\Delta \mathrm{t}_{\mathrm{f}}=$ fluid traveltime; and $\Delta \mathrm{t}_{\mathrm{log}}=$ traveltime from sonic log.

The traveltimes for the methane hydrate layer, the small limestone intervals, and the lower $50 \mathrm{~m}$ of Hole 570 are too fast to use the matrix velocity of $2.05 \mathrm{~km} / \mathrm{s}$ or $148.7 \mu \mathrm{s} / \mathrm{ft}$. for calculating porosity, and a large correction must be made to Equation 5 for valid porosity calculations. Changing Equation 5 from traveltime to velocity gives:

$$
\phi_{\mathrm{V}}=\frac{\mathrm{V}_{\mathrm{f}}}{\mathrm{V}_{\mathrm{log}}}\left[\frac{\mathrm{V}_{\mathrm{m}}-\mathrm{V}_{\mathrm{log}}}{\mathrm{V}_{\mathrm{m}}-\mathrm{V}_{\mathrm{f}}}\right]
$$

where $\phi_{\mathrm{V}}=$ porosity calculated from sonic log velocity; $\mathrm{V}_{\mathrm{m}}=$ matrix velocity; $\mathrm{V}_{\mathrm{f}}=$ fluid velocity; and $\mathrm{V}_{\log }=$ 
velocity from sonic log. Generalizing from this result, we arrive at

$$
\phi_{\mathrm{V}}=\mathrm{f}\left[\frac{1}{\mathrm{~V}_{\mathrm{log}}}\right]
$$

where $\phi_{\mathrm{V}}$ is a function of the inverse $\mathrm{V}_{\text {log. }}$.

From Equation 6 we see that as $V_{\log }$ increases the $\phi_{V}$ decreases and as $V_{\log }$ decreases the $\phi_{\mathrm{V}}$ increases. Cross plots of velocity from the sonic versus resistivity from the clld where both values are plotted on logarithmic scales for the interval of 1950 to $1980 \mathrm{~m}$ are shown in Figures 17 through 22 . These plots generally follow the logarithmic form of Archie's equation (Archie, 1942):

$$
\frac{\mathrm{R}_{\mathrm{o}}}{\mathrm{R}_{\mathrm{w}}}=\mathrm{a} \phi^{-\mathrm{m}} \text { or } \ln \mathrm{R}_{\mathrm{o}}=-\mathrm{m} \ln \phi+\ln \mathrm{aR}_{\mathrm{w}}
$$

where $R_{0}=$ formation resistivity $100 \%$ saturated with water of resistivity $R_{w} ; R_{w}=$ formation water resistivity; $\phi=$ porosity; $\mathrm{a}=$ constant; and $\mathrm{m}=$ constant, cement exponent. Combining Equations 6 and 7 gives:

$$
\ln R_{\mathrm{o}}=\mathrm{m} \ln [\mathrm{f}(\mathrm{v})]+\ln \mathrm{aR}_{\mathrm{w}}
$$

The slopes for most of these cross plots have an approximate value of either 5 or slightly greater than 5 . The only exception is seen in Figure 21 where the slope is 686 or nearly vertical. In this figure the massive methane hydrate zone shows a constant velocity versus a varying resistivity. Because the velocity plateaus for a 4-m interval without the resistivity showing a similar plateau, and because no empty intervals (such as sandstone-type rock with only $100 \%$ water-filled pore space) are present to gauge this 4-m interval, the cross plot data are only

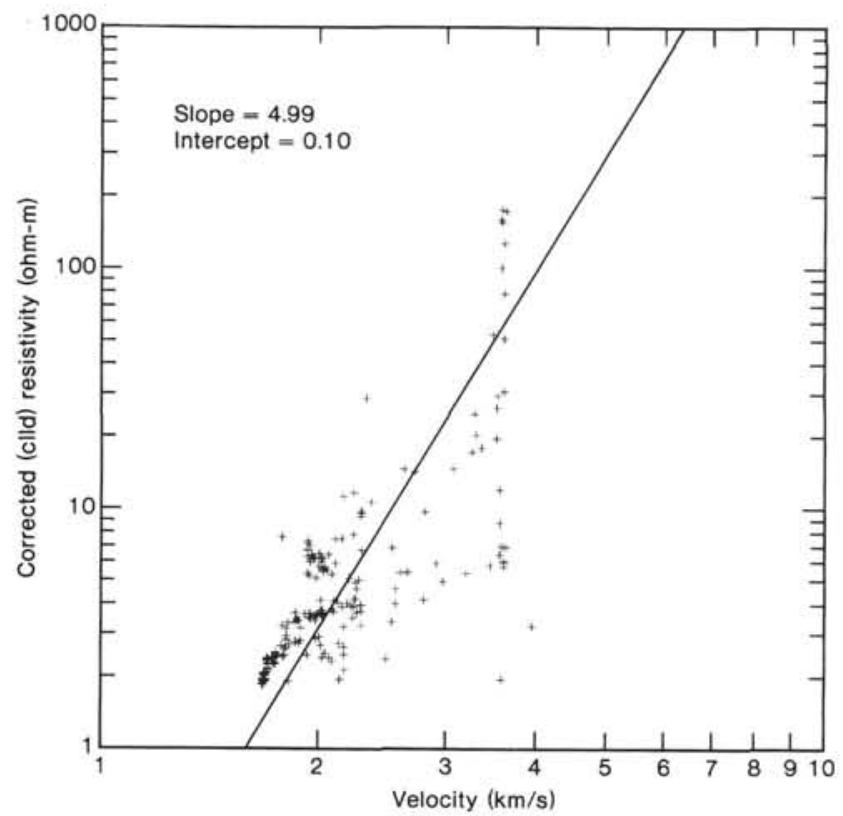

Figure 17. Logarithmic cross plot of resistivity (clld) versus velocity data from 1950 to $1980 \mathrm{~m}$.

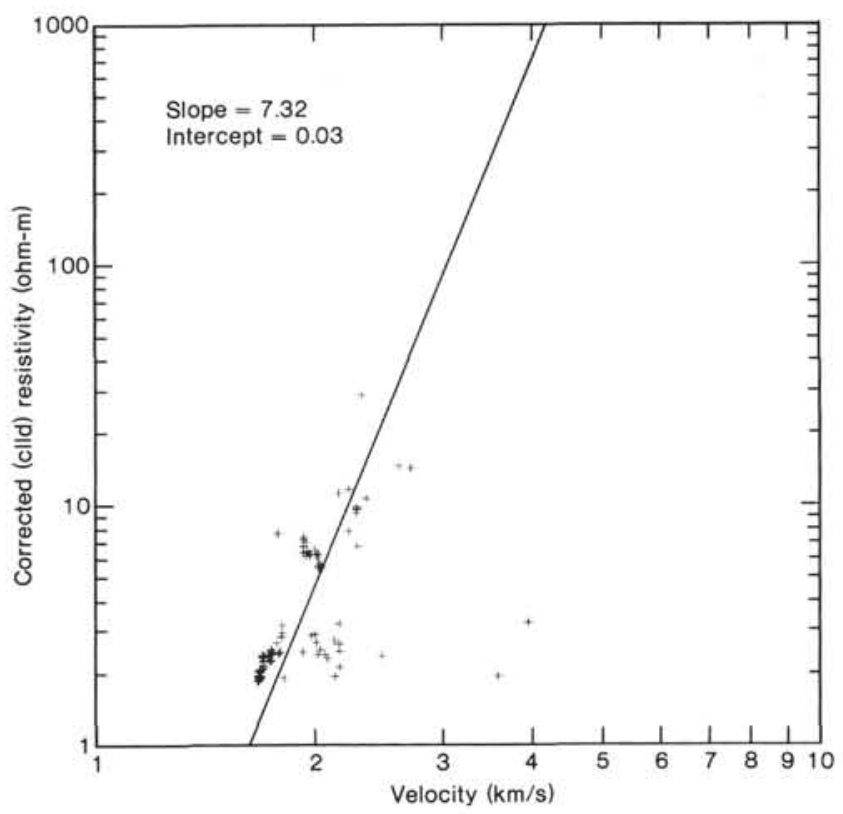

Figure 18. Logarithmic cross plot of resistivity (clld) versus velocity data from 1950 to $1980 \mathrm{~m}$, with the data from 1958.5 to $1973.5 \mathrm{~m}$ omitted.

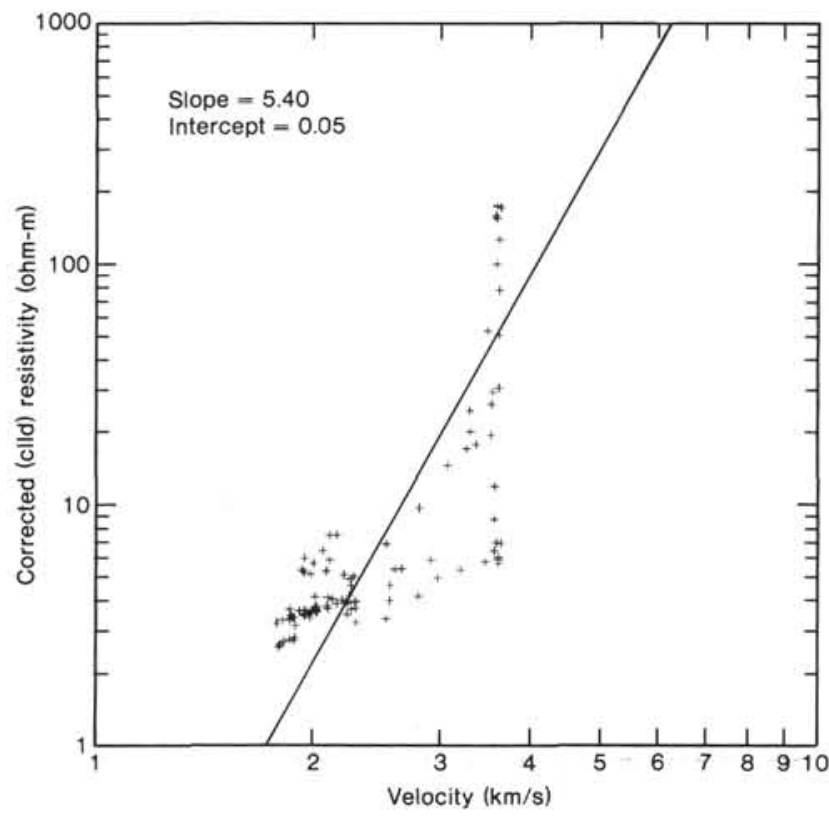

Figure 19. Logarithmic cross plot of resistivity (clld) versus velocity data from 1958.5 to $1973.5 \mathrm{~m}$.

used to indicate qualitatively the presence of methane hydrate.

In other methane hydrate deposits where hydrate has formed in sandstone or sand intervals and there are sand or sandstone intervals that are only $100 \%$ water filled, the cross plot of velocity porosity (velocity corrected for undercompaction) versus resistivity gives quantitative estimates of the amount of methane hydrate that exists in the pore spaces (Mathews, 1982, 1983). This is not the 


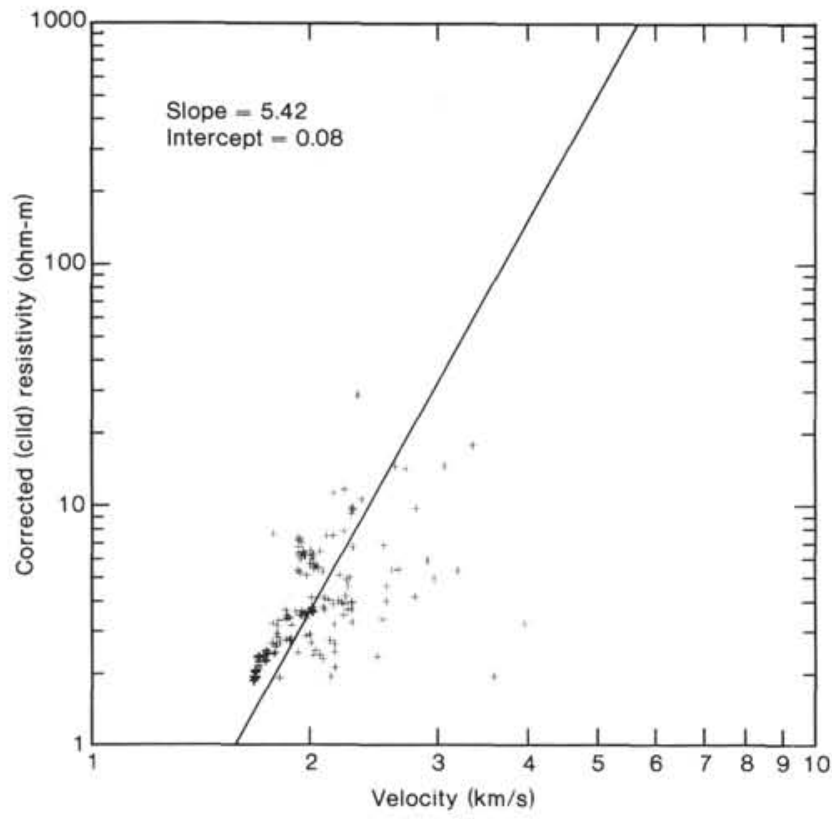

Figure 20. Logarithmic cross plot of resistivity (clld) versus velocity data from 1950 to $1980 \mathrm{~m}$, with the data from 1965.4 to $1969.4 \mathrm{~m}$ omitted.

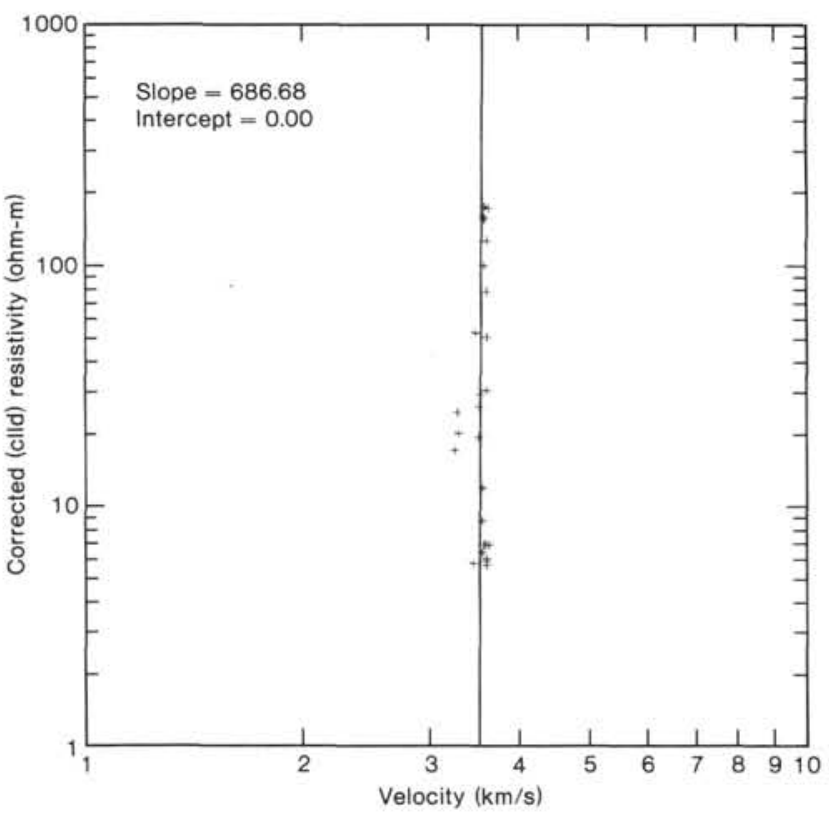

Figure 21. Logarithmic cross plot of resistivity (clld) versus velocity data from 1965.4 to $1969.4 \mathrm{~m}$.

case for the methane hydrate interval encountered in Hole 570.

The log responses that define both the methane hydrate layer and zone quantitatively are the p-wave velocity, density, and two laterologs. The true bulk density for the 1966.7 to $1969.4 \mathrm{~m}$ interval is 0.92 to $0.93 \mathrm{Mg}$ / $\mathrm{m}^{3}$. These are the densities for pure methane hydrate, as previously mentioned. This interval according to the density $\log$ is $100 \%$ methane hydrate where the methane hy-

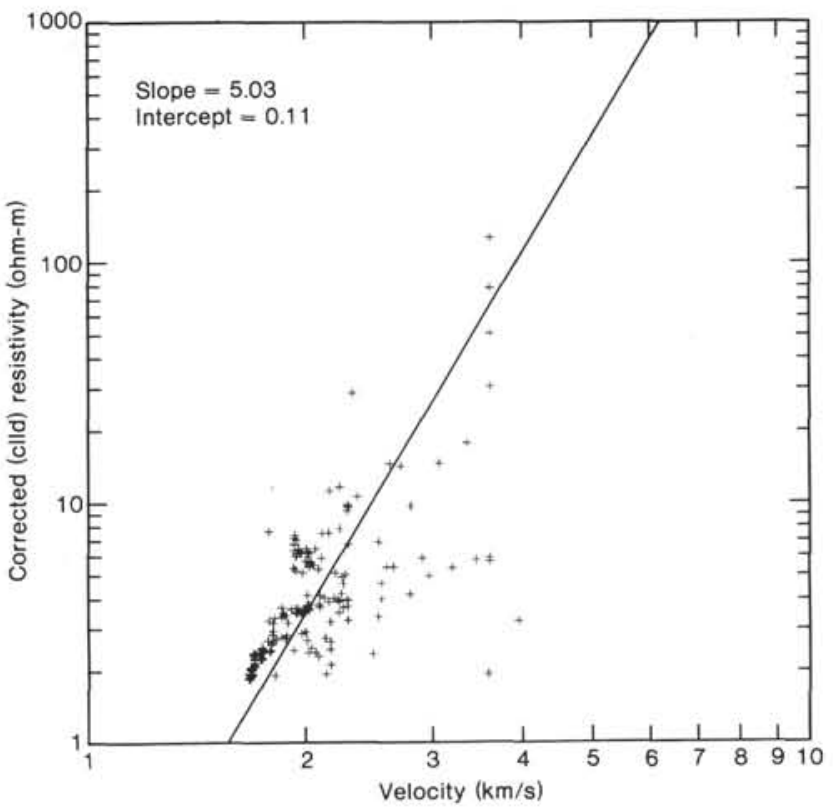

Figure 22. Logarithmic cross plot of resistivity (clld) versus velocity data from 1950 to $1980 \mathrm{~m}$, with the data from 1965.8 to $1968.7 \mathrm{~m}$ omitted.

drate has replaced the sediments and formation water completely. The interval of 1958.5 to $1973.5 \mathrm{~m}$ excluding the zone of 1966.7 to $1969.4 \mathrm{~m}$ has a decrease of $0.1 \mathrm{Mg} / \mathrm{m}^{3}$ from the average $1.75 \mathrm{Mg} / \mathrm{m}^{3}$. If this 0.1 $\mathrm{Mg} / \mathrm{m}^{3}$ decrease is the result of methane hydrate replacing the rock matrix and formation water, then this interval is $94 \%$ matrix and water and $6 \%$ methane hydrate. Table 3 lists the methane hydrate content as calculated from the density log where the methane hydrate has replaced some or all of the rock matrix material and formation water. Normally methane hydrate is formed in the pore spaces of the host rock (reservoir rock like sandstone, sand, etc.) and replaces the fluid in these pore spaces. This is not the case in Hole 570.

The p-wave velocity data present a different picture. The velocity increases from 1.77 to $3.6 \mathrm{~km} / \mathrm{s}$ in the interval from 1958.5 to $1965.4 \mathrm{~m}$. The velocity plateaus at $3.6 \mathrm{~km} / \mathrm{s}$ from 1965.4 to $1969.5 \mathrm{~m}$ except for a small zone from 1967.4 to $1968 \mathrm{~m}$ where the velocity decreases to $3.3 \mathrm{~km} / \mathrm{s}$. The velocity decreases from 3.60 to $1.77 \mathrm{~km} / \mathrm{s}$ in the interval from 1969.4 to $1973.5 \mathrm{~m}$. Using a velocity of $3.73 \mathrm{~km} / \mathrm{s}$ for $100 \%$ methane hydrate and taking the ratio of p-wave velocity to $3.73 \mathrm{~km} / \mathrm{s}$ yields the methane hydrate content as calculated from the velocity where the methane hydrate has replaced some

Table 3. Methane hydrate content from density data.

\begin{tabular}{ccc}
\hline $\begin{array}{c}\text { Interval } \\
(\mathrm{m})\end{array}$ & $\begin{array}{c}\text { Thickness } \\
(\mathrm{m})\end{array}$ & $\begin{array}{c}\text { Methane hydrate } \\
(\%)\end{array}$ \\
\hline $1958.5-1966.7$ & 8.2 & 6 \\
$1966.7-1969.4$ & 2.7 & 100 \\
$1969.4-1973.5$ & 4.1 & 6 \\
\hline
\end{tabular}


or all of the rock matrix material and formation water. Table 4 lists the methane hydrate content as calculated from the sonic log ( $\mathrm{p}$-wave velocity).

The resistivity data were obtained from the LLs and LLd laterologs. The data were corrected for borehole and bed-thickness effects (see Figs. 10 and 11) and renamed clls and clld for the corrected laterolog resistivities. These data clearly indicate the methane hydrate layer and massive methane hydrate zone by the increase in resistivity. This increase in resistivity correlates with the increase in velocity and the decrease in density. The velocity and density data plateau for $4.0 \mathrm{~m}$ and $2.7 \mathrm{~m}$, respectively, and the resistivity data from both laterologs plateau, or nearly flatten out, at 1968.2 to 1968.8 for $0.6 \mathrm{~m}$ starting at $136 \mathrm{ohm}-\mathrm{m}$ for the clls and starting at $140 \mathrm{ohm}-\mathrm{m}$ for the clld. There are no reported resistivities for pure methane hydrate. Methane hydrate is an electrical insulator and the resistivity is largely controlled by the unfrozen brine inclusions. Recent experimental work (Pearson et al., 1984) shows that sonic velocities rapidly increased as hydrates began to form, but soon approached a limiting value (the velocity plateau) even though more hydrate was formed. In contrast, resistivities rapidly increased as hydrates began to form and continued to increase rapidly as more hydrate formed and the amount of unfrozen brine decreased. No limiting value or resistivity plateau was encountered in this experimental work. Resistivity plateaus or limiting values were observed in other massive hydrate layers (Mathews, 1982, 1983) and were used to indicate a $100 \%$ methane hydrate zone. In those zones, it was assumed that the complete or nearly total pore spaces in the rocks were entirely filled with methane hydrate and little or no unfrozen brine was present.

The resistivity data for Hole 570 in the massive methane hydrate zone were observed to plateau, or nearly plateau, and this flattening was taken as the $100 \%$ methane hydrate interval with no or very little rock matrix material and formation or brine water present. The resistivity was normalized (both clls and clld) and plotted in Figures 23 and 24. It is assumed in these plots that a value of 1.0 indicates $100 \%$ pure methane hydrate. The interval at 1968.2 to $1968.8 \mathrm{~m}$ where the resistivity data flatten out has a normalized value of 0.85 to 1.0 on both figures. These plots for both normalized resistivity data yield nearly identical methane hydrate content as listed in Tables 5 and 6 where the methane hydrate has replaced some or all of the rock matrix material and formation water.

Table 4. Methane hydrate content from velocity data.

\begin{tabular}{ccc}
\hline $\begin{array}{c}\text { Interval } \\
(\mathrm{m})\end{array}$ & $\begin{array}{c}\text { Thickness } \\
(\mathrm{m})\end{array}$ & $\begin{array}{c}\text { Methane hydrate } \\
(\%)\end{array}$ \\
\hline $1958.5-1963.8$ & 5.3 & 27.0 \\
$1963.5-1965.4$ & 1.9 & 48.3 \\
$1965.4-1967.4$ & 2.0 & 96.5 \\
$1967.4-1968.0$ & 0.6 & 88.5 \\
$1968.0-1969.4$ & 1.4 & 96.5 \\
$1969.4-1970.6$ & 1.2 & 48.3 \\
$1970.4-1973.5$ & 3.1 & 29.5 \\
\hline
\end{tabular}

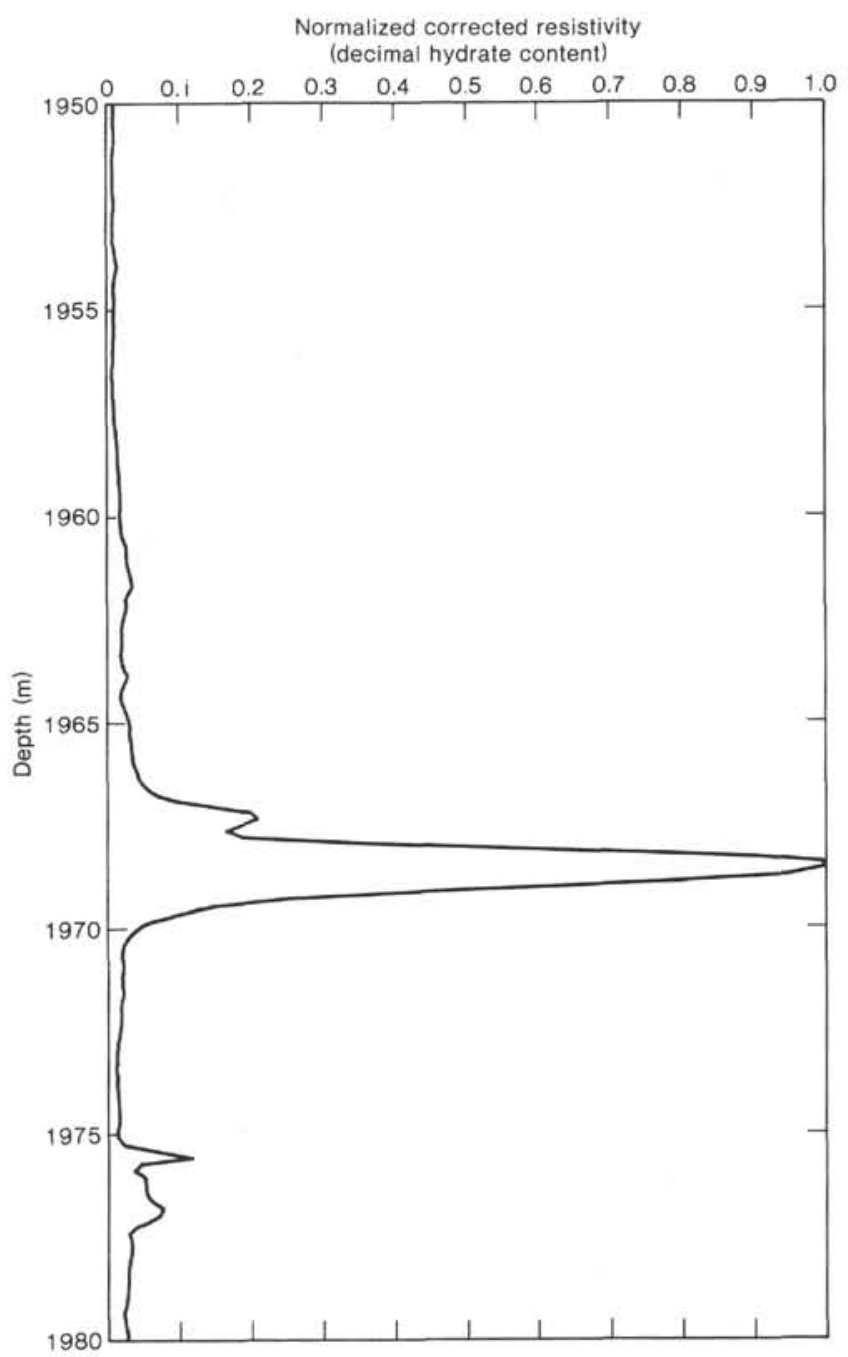

Figure 23. Normalized corrected resistivity data (clls) from 1950 to $1980 \mathrm{~m}$ correspond to decimal hydrate content.

An estimate of methane gas in place will be made using the data in Tables 3 through 6 . A unit cell of methane hydrate can have a Type 1 or Type 2 crystal structure (Barraclough, 1980). A Type 1 structure has 46 water molecules in which the hydrogen atoms are bonded to each other in a manner similar to water ice with 8 cavities within this lattice; this allows a unit cell to have 46 water molecules and 8 guest molecules if all cavities are filled. A Type 2 structure has 136 water molecules in which the hydrogen atoms are bonded to each other in a manner similar to water ice with 8 large and 16 smaller cavities within this lattice; this allows a unit cell to have 136 water molecules and 24 guest molecules if all cavities are filled.

An ideal unit cell of methane hydrate would be a Type 1 crystal structure where the guest molecule's largest dimension is less than $5.8 \AA$, and $\mathrm{CH}_{4}$ would be the guest molecule. This cell would contain 46 water molecules (molecular weight $=18$ ) and 8 methane molecules (molecular weight $=16)$. One mole of unit cells (46 water and 8 methane) has a weight of $0.956 \mathrm{~kg}(2.1076 \mathrm{lb}$.). Pure water weighs $1000 \mathrm{~kg} / \mathrm{m}^{3}$, and the density of meth- 


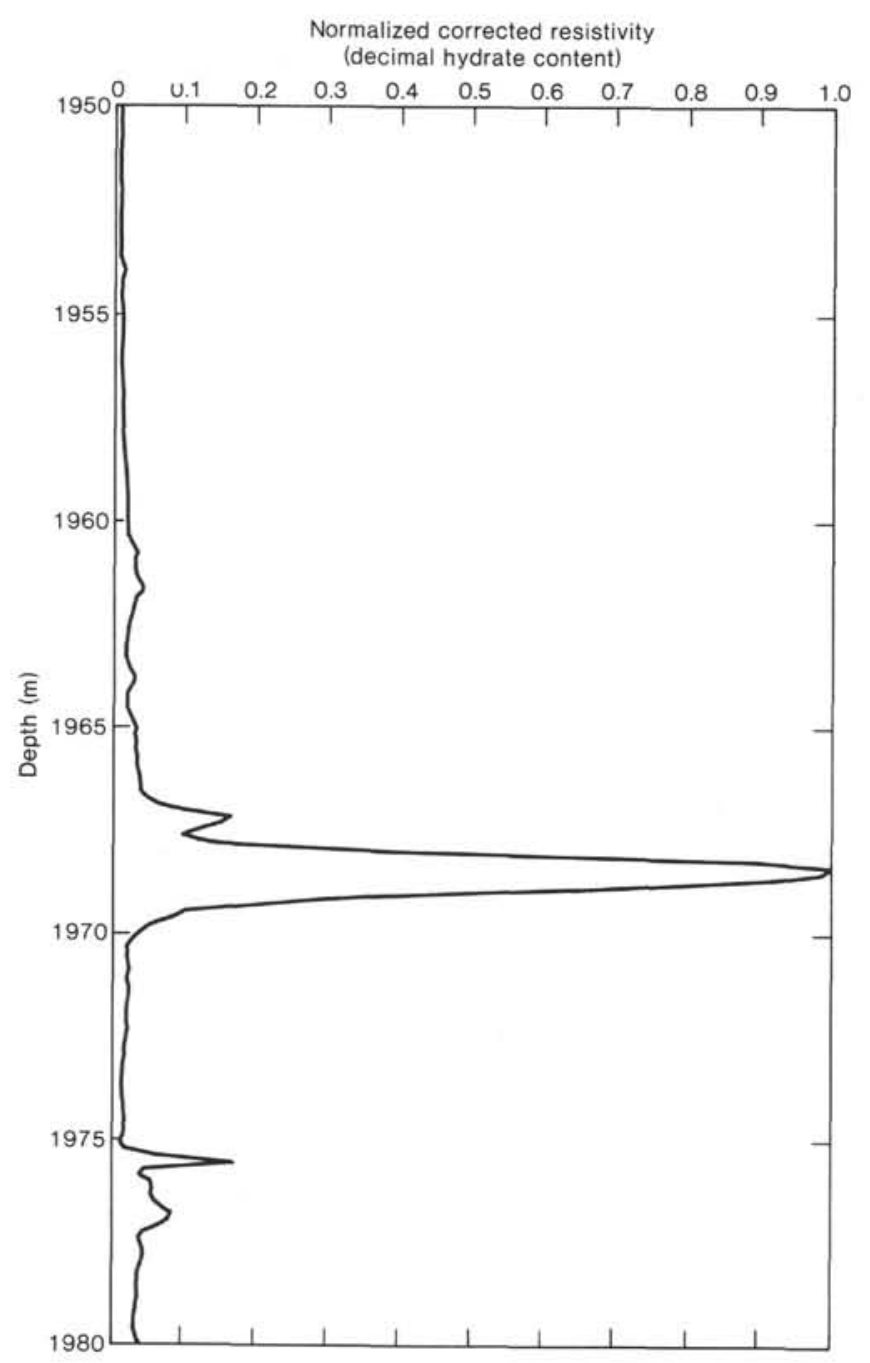

Figure 24. Normalized corrected resistivity data (clld) from 1950 to $1980 \mathrm{~m}$ correspond to decimal hydrate content.

Table 5. Methane hydrate content from clls normalized resistivity data.

\begin{tabular}{ccc}
\hline $\begin{array}{c}\text { Interval } \\
(\mathrm{m})\end{array}$ & $\begin{array}{c}\text { Thickness } \\
(\mathrm{m})\end{array}$ & $\begin{array}{c}\text { Methane hydrate } \\
(\%)\end{array}$ \\
\hline $1958.5-1966.15$ & 7.65 & 3 \\
$1966.15-1967.15$ & 1.0 & 9.5 \\
$1967.15-1967.9$ & 0.75 & 19 \\
$1967.7-1968.2$ & 0.5 & 21 \\
$1968.2-1968.8$ & 0.6 & 97.5 \\
$1968.8-1969.4$ & 0.6 & 25.5 \\
$1969.4-1970.15$ & 0.75 & 5 \\
$1970.15-1973.5$ & 3.35 & 2 \\
\hline
\end{tabular}

ane hydrate is 0.92 times the density of water. One cubic meter of methane hydrate weighs $920 \mathrm{~kg}$ and contains 962.34 moles of unit cells. Each unit cell contains 8 methane molecules, and the number of moles of methane in $1 \mathrm{~m}^{3}$ of methane hydrate is 7698.72 . One mole of methane at an atmospheric pressure of $0.1016 \mathrm{MPa}$ $(14.73 \mathrm{psia})$ and the base temperature of $15.56^{\circ} \mathrm{C}\left(60^{\circ} \mathrm{F}\right)$ used by the natural gas industry occupies a volume of $0.0237 \mathrm{~m}^{3}\left(0.837 \mathrm{ft}^{3}\right)$. Consequently, the methane con-
Table 6. Methane hydrate content from clld normalized resistivity data.

\begin{tabular}{ccc}
\hline $\begin{array}{c}\text { Interval } \\
(\mathrm{m})\end{array}$ & $\begin{array}{c}\text { Thickness } \\
(\mathrm{m})\end{array}$ & $\begin{array}{c}\text { Methane hydrate } \\
(\%)\end{array}$ \\
\hline $1958.5-1966.15$ & 7.65 & 3 \\
$1966.15-1966.9$ & 0.75 & 5 \\
$1966.9-1967.8$ & 0.90 & 13 \\
$1967.7-1968.2$ & 0.50 & 21 \\
$1968.2-1968.8$ & 0.60 & 98 \\
$1968.8-1969.4$ & 0.60 & 25.5 \\
$1969.4-1970.15$ & 0.75 & 4 \\
$1970.15-1973.5$ & 3.35 & 2 \\
\hline
\end{tabular}

tent of $1 \mathrm{~m}^{3}$ of methane hydrate corresponds to 182.46 standard $\mathrm{m}^{3}$ of methane gas.

A list of the estimates of methane gas for an area of $1 \mathrm{~m}^{2}$, times the thickness (m) of methane hydrate, times the percentage of methane hydrate, times 182.46 standard $\mathrm{m}^{3}$ of methane gas per $\mathrm{m}^{3}$ of methane hydrate is given in Table 7 from the various estimates of methane hydrate (Tables 3 through 6).

This estimate ranges from $1396.7 \times 10^{6} \mathrm{~m}^{3}$ per $\mathrm{km}^{2}$ $\left(127.75 \times 10^{9} \mathrm{ft}^{3}\right.$ per square mile) to $242.1 \times 10^{6} \mathrm{~m}^{3}$ per $\mathrm{km}^{2}\left(22.14 \times 10^{9} \mathrm{ft}^{3}\right.$ per square mile). This is an extremely wide range, but if we use the normalized clld data estimate, which is the lowest estimate, this still is a large quantity of natural gas. Because the methane hydrate body at Site 570 cannot be traced in seismic records, its shape and extent are unknown. The geologic setting of the massive hydrate and Site 570-near a transverse furrow (Volpe et al., this volume), which is probably a fault, and at a hiatus in the sedimentary sequencefavors the association of this massive hydrate with a fault zone rather than with a layer along an unconformity. Presumably, the massive hydrate may have formed during progressive movement along the fault and perhaps a rhombochasm opened incrementally. Any freegas migration along the fault would hydrate as it filled the void left during fault movement. Other gas hydrate at Site 570 was observed to occupy fractures in the massive mudstone or pore space in vitric sand layers. However, so little is known regarding the emplacement of gas hydrate in the marine environment that a layer of fractured mudstone and dolomite filled with hydrate cannot be ruled out.

\section{LOGGING RECOMMENDATIONS FOR FUTURE SITES}

On all future sites where methane hydrate may be core drilled in a deep sea drilling program we recommend that specific logs be run in each hole and that they be recorded on magnetic tape for data processing and

Table 7. Methane gas estimate per area.

\begin{tabular}{lccc}
\hline Log data & $\begin{array}{c}\text { Thickness }(\mathrm{m}) \\
\times \% \text { methane hydrate } \\
\times \text { area }\left(1.0 \mathrm{~m}^{2}\right)\end{array}$ & $\begin{array}{c}\text { Cubic meters of } \\
\text { methane gas } \\
\text { per } \mathrm{m}^{2} \text { area }\end{array}$ & $\begin{array}{c}\text { Cubic meters of } \\
\text { methane gas } \\
\text { per } \mathrm{km}^{2}\end{array}$ \\
\hline Density & 3.44 & 627.7 & $627.7 \times 10^{6}$ \\
Velocity & 7.65 & 1396.7 & $1396.7 \times 10^{6}$ \\
Normalized clls & 1.41 & 258.1 & $258.1 \times 10^{6}$ \\
Normalized clld & 1.33 & 242.1 & $242.1 \times 10^{6}$ \\
\hline
\end{tabular}


analyzing techniques. These logs, which would define the methane hydrate thickness and aid in quantitatively estimating the amount of methane hydrate and methane gas encountered, are:

Four-arm caliper (direction and inclination parameters of this tool would be very useful, but not absolutely necessary)

Temperature

Density, litho-density

Epithermal neutron

High-quality gamma-ray on ever log run, including temperature and caliper

Dual laterolog with the spherically focussed log

Regular sonic and long-spaced sonic

Full-wave sonic (with all data recorded on magnetic tape)

Pulsed neutron decay logs (neutron lifetime or thermal decay time logs)

Carbon-oxygen log (neutron activation log)

\section{CONCLUSIONS}

At DSDP Site 570, on the landward slope of the Middle America Trench off Guatemala, a body of nearly pure methane hydrate was penetrated. The body probably formed along a fault that has seafloor expression where the hole was spudded in, but it might also be from a layer of mixed hydrate and sediment formed along an unconformity. This body has sufficient volume to produce an in situ log response to pure hydrate and thus allow calibration of various logs for a quantitative estimate of hydrate content.

The zone of methane hydrate is $15 \mathrm{~m}$ thick, as defined by resistivity, sonic, and density well log data; a zone of nearly pure methane hydrate about $4 \mathrm{~m}$ thick corresponding in depth to the core in which $1.5 \mathrm{~m}$ of hydrate were recovered is recognized on the sonic, density, resistivity, gamma-ray, and neutron porosity well log data. Above and below the zone, methane hydrate filling fractures in massive mudstone was observed visually in cores, but the quantitative estimates from well log data indicate less than about $5 \%$ hydrate content.

Examination of the acoustic impedance as calculated from the density and sonic logs show no anomalous acoustic impedance conditions for the massive hydrate layer. This is probably the reason that no anomalous seismic reflections are observed in the seismic records across the site and so the extent and shape of the body cannot be determined. A methane gas estimate of this hydrate layer ranges from $240 \times 10^{6} \mathrm{~m}^{3}$ to $1400 \times 10^{6} \mathrm{~m}^{3}$ per $\mathrm{km}^{2}$ of lateral extent ( 20 to 130 billion $\mathrm{ft}^{3}$ per square mile) if this hydrate layer is continuous and of broad areal extent.

In the future, quantitative estimates of gas hydrate content near the borehole can be made if the proper well $\log$ data are obtained. Such estimates are not otherwise possible, even with continuous coring, because the gas hydrate disassociates during core retrieval or is so finely dispersed as to be megascopically imperceptible. The chemistry of associated pore fluid can show when hydrate is present, but it cannot yet be used as a quantitative indicator of hydrate content.

\section{REFERENCES}

Archie, G. E., 1942. The electrical resistivity log as an aid in determining some reservoir characteristics. Trans. AIME, 146:54-62.

Barraclough, B. L., 1980. Methane hydrates as an energy resource: a review with recommendations for future research. Los Alamos National Laboratory Report No. LA-8368-MS.

Ladd, J. W., Ibrahim, A. K., McMillen, K. J., Latham, G. V., and von Huene, R., 1892. Interpretation of seismic reflection data of the Middle America Trench offshore Guatemala. In Aubouin, J., von Huene, R., et al., Init. Repts. DSDP, 67: Washington (U.S. Govt. Printing Office),, 675-689.

Macleod, M. D., 1982. Gas hydrates in ocean bottom sediments. AAPG Bulletin, 66(12):2649-2662.

Makogen, Y. F., Trebin, F. A., Trofimuk, A. A., Tsarev, V. P., and Cherskii, N. V., 1971. Detection of a pool of natural gas in a solid (gas hydrate) state. Dokl. Akad. Sci. USSR, Earth Sci. Sect., 196: 197-200.

Mathews, M. A., 1982. Logging characteristics of methane hydrate [paper presented at December 15, 1982 meeting of SPWLA Denver Well Logging Society Chapter].

1983. Logging characteristics and methane gas estimate of methane hydrate deposits [paper presented at September 28, 1983 meeting of SPWLA Four Corners Well Logging Society Chapter].

Pearson, C. F., 1982. Physical properties of natural gas hydrate deposits. Los Alamos National Laboratory Report No. LA-9422-MS.

Pearson, C. F., Halleck, P. M., McGuire, P. L., Hermes, R. E., and Mathews, M. A., 1983a. Natural gas hydrates deposits: a review of in situ properties. J. Phys. Chem., 87(21):4180-4185.

Pearson, C. F., Murphy, J. R., Halleck, P. M., Hermes, R. E., and Mathews, M. A., 1983b. Sonic and resistivity measurements on Berea sandstone containing tetrahydrofuran hydrates: a possible analog to natural gas hydrate deposits. Proc. Fourth Int. Conf. Permafrost, Washington, D. C. (National Academy Press), pp. 973-978.

Pearson, C. F., Murphy, J. R., Hermes, R. E., and Halleck, P. M., 1984. Laboratory ultrasonic and resistivity measurements on sedimentary rocks containing tetrahydrofuran hydrates. Los Alamos National Laboratory Report No. LA-9972-MS.

Schlumberger, 1972. Log Interpretation. Principles (Vol. 1): New York (Schlumberger Limited).

Scott, M. I., Randolph, P. L., and Pangborn, J. B., 1980. Assessment of methane hydrates. Institute of Gas Technology Report No. GRI-79-0070.

Shipley, T. H., Ladd, J. W., Buffler, R. T., and Watkins, J. S., 1982. Tectonic processes along the Middle America Trench inner slope. In Leggett, J. K. (Ed.) Trench and forearc geology: sedimentation and tectonics on modern and ancient active plate margins, Geol. Soc. London, Spec. Publ. 10, Blackwell Scientific Publication, Oxford, pp. 95-106.

von Huene, R., Ladd, J., and Norton, I., 1982. Geophysical observations of slope deposits, Middle America Trench off Guatemala. In Aubouin, J., von Huene, R., et al., Init. Repts. DSDP, 67: Washington (U.S. Govt. Printing Office), 67:719-731.

Wyllie, M. R. J., Gregory, A. R., and Gardner, G. H. F., 1956. Elastic wave velocities in heterogenous and porous media. Geophysics, 21(1):41-70.

, 1958. An experimental investigation of factors affecting elastic wave velocities in porous media. Geophysics, 23(3):459-493. 